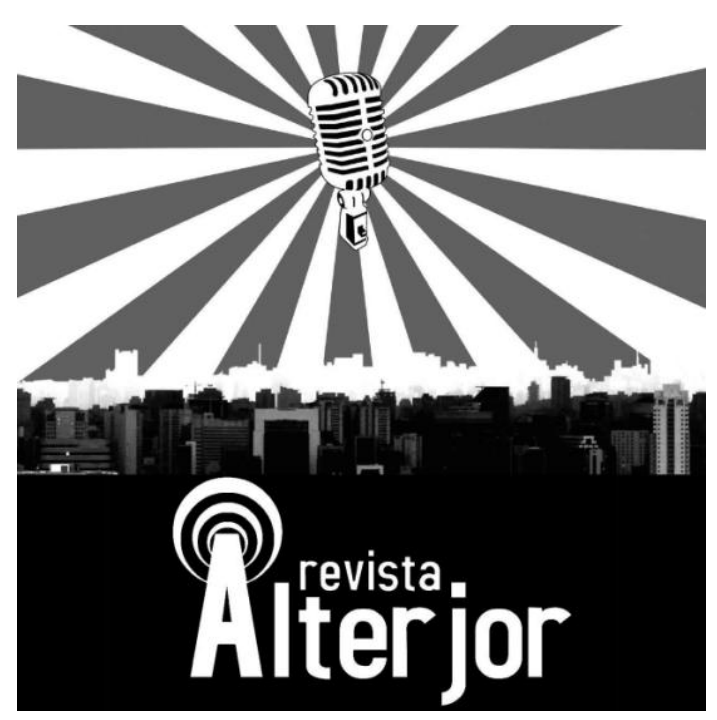

RELATÓRIO DE PESQUISA

\title{
COMUNICAÇÃO DE RESISTÊNCIA: A MÍDIA ALTERNATIVA BRASILEIRA ON-LINE NA LUTA PELOS DIREITOS HUMANOS
}

\author{
Veronica de Paula da Rocha Alves ${ }^{1}$
}

\begin{abstract}
RESUMO: Considerando o cenário brasileiro atual, caracterizado pela ascensão do conservadorismo, fragilização da democracia e desmonte de direitos, este artigo busca compreender como o conteúdo produzido e as estratégias utilizadas pela mídia alternativa, ao abordar pautas relacionadas aos direitos humanos, podem auxiliar nessa luta. Neste estudo qualitativo e exploratório, utiliza-se um questionário como instrumento para coleta de dados, aplicado para representantes de veículos de mídia alternativa atuantes no país: Ponte Jornalismo, Voz das Comunidades, Jornalistas Livres e The Intercept Brasil. Além disso, é realizada uma pesquisa documental por meio de um levantamento dos conteúdos publicados, durante três meses, no Facebook dos participantes.
\end{abstract}

PALAVRAS-CHAVE: Direitos Humanos. Mídia alternativa. Comunicação. Democracia.

ABSTRACT: Considering the current Brazilian scenario, characterized by the rise of conservatism, the weakening of democracy and the dismantling of rights, this article seeks to understand how the content produced and the strategies used by alternative media, when addressing agendas related to human rights, can help in this struggle. In this qualitative and exploratory study, a questionnaire is used as an instrument for data collection, applied to representatives of alternative media in the country: Ponte Jornalismo, Voz das Comunidades, Jornalistas Livres and The Intercept Brasil. In addition, a documental research is carried out through a survey of the contents published, for three months, on the participants' Facebook.

KEYWORDS: Human rights. Alternative media. Communication. Democracy.

\footnotetext{
${ }^{1}$ Jornalista (PUCPR), com experiência em criação de conteúdo em diferentes formatos para redes sociais e blogs. Mestra em Direitos Humanos e Políticas Públicas (PUCPR), pesquisadora das aproximações entre mídia alternativa, comunicação e direitos humanos. E-mail: veronicapralves@hotmail.com.
}

\section{Revista ALTERJOR}

Grupo de Estudos Alterjor: Jornalismo Popular e Alternativo (ECA-USP)

Ano 12 - Volume 01 - Edição 25 - Janeiro-Junho de 2022

Av. Professor Lúcio Martins Rodrigues, 443, Cidade Universitária, São Paulo, CEP: 05508-020 


\section{INTRODUÇÃO}

Compreender os direitos humanos, considerando em especial a realidade latinoamericana, impõe-nos a necessidade de refletir sobre o efeito que aspectos sociais, políticos, econômicos, históricos e culturais exercem em suas diferentes concepções teóricometodológicas. Ao reconhecer os direitos humanos como resultado das relações em sociedade, entendemos que eles são, dessa forma, uma construção social. Por essa razão, nesta pesquisa, partimos de uma perspectiva teórica crítica e decolonial (FLORES, 2009; GALLARDO, 2014; SANTOS, 2014), que coloca os movimentos sociais e as novas formas de organização da sociedade civil em uma posição central na construção dos direitos humanos, por meio de processos e lutas que dão visibilidade às desigualdades e denunciam as violações de direitos.

A ação desses representantes da sociedade civil é o que dá luz às condições ideopolíticas para o estabelecimento de uma nova cultura de direitos humanos. Contudo, é fundamental destacar que as garantias e legislações elaboradas pelo Estado ainda estão muito longe das narrativas e reivindicações dos movimentos que lutam por direitos. A realidade da maior parte da população difere muito do que retrata nossa Constituição, especialmente a das pessoas que vivenciam as desigualdades social, étnico-racial e de gênero, que estão à margem em territórios vulneráveis com difícil ou nenhum acesso aos bens, à renda e a políticas públicas.

Nos últimos anos, as lutas sociais para mudar essa realidade têm sido cada vez mais importantes e necessárias devido ao crescimento do conservadorismo e a ascensão da extrema direita e do neoliberalismo, que constituem o plano de fundo de um cenário perigoso para os direitos humanos no Brasil e no mundo. Vivenciamos um desmonte de direitos, que foram resultados históricos de lutas sociais importantes. Exemplos desses retrocessos são a aprovação da PEC do teto de gastos públicos, que limita os investimentos nos setores que mais precisam, e as reformas trabalhista e da previdência, que tiram dos trabalhadores direitos há muito conquistados e fortalecem as relações de exploração, escancarando a desigualdade social gerada pelo conflito entre o capital e o trabalho.

Nesse contexto, os movimentos sociais precisam encontrar novas formas de organização para resistir aos ataques à democracia e lutar pela dignidade humana. E, para tanto, a comunicação exerce um papel central. Afinal, mesmo que ainda pouco reconhecido, comunicarse é um direito tão fundamental quanto ter acesso à educação e à saúde, por exemplo. É por meio da comunicação que uma sociedade se desenvolve.

Contudo, comunicar-se no Brasil não é um direito de todos, muito menos um direito humano. Os meios de comunicação ficam concentrados sob o poder de poucas famílias, que os controlam de acordo com seus próprios interesses, construindo narrativas que, muitas vezes, são contrárias à luta pela dignidade humana. Nas sociedades contemporâneas, esses meios são necessários para transmitir e receber mensagens de maneira efetiva e dar voz aos diferentes grupos sociais. Assim, a ausência de pluralidade nos meios de comunicação e a falta de acesso a eles representa uma ameaça à própria democracia.

É considerando tal cenário que nos dedicamos a estudar a atuação da mídia alternativa, que surge justamente em períodos de fragilização da democracia. Representada por veículos que

\footnotetext{
Revista ALTERJOR

Grupo de Estudos Alterjor: Jornalismo Popular e Alternativo (ECA-USP)

Ano 12 - Volume 01 - Edição 25 - Janeiro-Junho de 2022

Av. Professor Lúcio Martins Rodrigues, 443, Cidade Universitária, São Paulo, CEP: 05508-020
} 


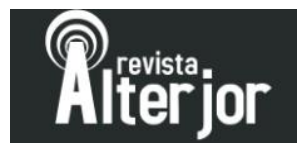

desafiam os oligopólios de comunicação, atualmente, a mídia alternativa encontra espaço na internet para se desenvolver e se estabelece como uma aliada da luta social por direitos humanos, na medida em que nela "é dada voz aos que não têm voz, que denunciam as injustiças, reivindicam direitos, combatem o status quo." (GOÉS, 2007, p. 6).

Dessa forma, a mídia alternativa apresenta um grande potencial para fortalecer a luta por direitos humanos. O que nos resta saber é: quais os espaços e estratégias dessa mídia na perspectiva de elaborar pautas relacionadas aos direitos humanos? É partindo disso que investigamos a atuação da mídia alternativa, em especial os veículos de jornalismo independente, no combate à intolerância, na resistência ao conservadorismo e na promoção da igualdade e da democracia.

É na medida em que busca se opor a isso que essa mídia se torna o lar de pautas e histórias que, por uma série de motivos (conselho do governo, pressão comercial de anunciantes, conservadorismo, prioridades próprias dos veículos etc.), não encontram espaço na grande mídia. Dessa forma, a mídia alternativa se impõe como uma mídia contra-hegemônica, geralmente, ficando ao lado dos movimentos sociais e de minorias que buscam mudanças e lutam por direitos, fornecendo ao público informações que simplesmente não são encontradas em outros lugares.

Discutida há vários anos dentro do campo da comunicação - antes da popularização da internet -, a mídia alternativa representa um conceito que abrange uma grande diversidade de fatores e, consequentemente, divide teóricos quanto à sua definição. A variedade de denominações para o mesmo fenômeno, ou ao menos para fenômenos muitos parecidos, é vasta: comunicação alternativa, meios alternativos, imprensa alternativa, jornalismo alternativo, jornalismo independente, comunicação comunitária, mídia radical, mídia underground e mídia contra hegemônica são alguns dos exemplos.

Para o desenvolvimento desta pesquisa, escolhemos o termo mídia alternativa por entender que se trata do mais amplo, completo e comum entre eles. O que buscamos é defini-la e compreendê-la não apenas pelo seu conteúdo e formato, mas também pelos processos e pelas relações em que ela se desenvolve e que afetam sua produção. Por isso, recorremos aos estudos de Chris Atton (2002), um dos principais pesquisadores atuais do tema, e de Máximo Simpson Grinberg (1987), cuja obra ainda é base para qualquer reflexão teórica sobre o assunto.

Em seu estudo sobre as aproximações entre a comunicação popular e comunitária e a imprensa alternativa brasileira na era do ciberespaço, Cicilia Peruzzo (2009) destaca a intermitência da mídia alternativa e sua capacidade de se regenerar com o passar do tempo. Para ela, o jornalismo alternativo "reedita formas de expressão impressas e audiovisuais, cria novos canais e, ao mesmo tempo, se recria por meio de novos formatos digitais que o avanço tecnológico favorece. Mas permanece seu caráter alternativo." (PERUZZO, 2009, p. 137).

Segundo a autora, ao inverter a lógica de produção - antes centrada em apenas um emissor que se dirigia a muitos e agora permitindo que todos se dirijam a todos - a internet aumenta as possibilidades de comunicação e de participação social. Nesse cenário, então, os

\footnotetext{
Revista ALTERJOR

Grupo de Estudos Alterjor: Jornalismo Popular e Alternativo (ECA-USP)

Ano 12 - Volume 01 - Edição 25 - Janeiro-Junho de 2022

Av. Professor Lúcio Martins Rodrigues, 443, Cidade Universitária, São Paulo, CEP: 05508-020
} 
movimentos sociais se apropriam dos espaços gerados pelas novas mídias digitais, criando formas inéditas de militância e ativismo nas redes.

A seguir, estudaremos a atuação de quatro representantes da mídia alternativa brasileira de hoje para compreender, na prática, como acontecem essas novas manifestações, especialmente no âmbito dos direitos humanos. Utilizando a internet como meio, esses veículos podem oferecer novos espaços aos movimentos sociais que lutam por direitos, ampliando as possibilidades de transformação e desenvolvimento por meio da comunicação.

\section{PARTICIPANTES DA PESQUISA}

De modo geral, por abrangerem um universo muito grande, é praticamente impossível considerar todos os elementos que fazem parte de uma pesquisa (GIL, 2002). Assim, torna-se necessário trabalhar com uma amostra, ou seja, um pequeno número dos elementos que compõem determinado universo. Gil (2002, p.121) afirma que "quando essa amostra é rigorosamente selecionada, os resultados obtidos no levantamento tendem a aproximar-se bastante dos que seriam obtidos caso fosse possível pesquisar todos os elementos do universo."

Diante do fato de que ainda não há dados oficiais sobre o número de veículos jornalísticos que podem ser caracterizados como mídia alternativa trabalhando no Brasil, foi utilizado como base para identificação desse universo o Mapa do Jornalismo Independente, criado pela Agência Pública (2019). Além disso, foram considerados o conhecimento prévio da pesquisadora sobre o trabalho dos veículos e as características apontadas pelos autores estudados sobre a mídia alternativa, que ajudaram a identificar os possíveis participantes.

Dessa forma, foram estabelecidos os seguintes critérios para recorte dos participantes de pesquisa:

Quadro 1 - Critérios para escolha dos participantes da pesquisa

Critérios

1. Ser idealizado e/ou produzido por jornalistas e a maior parte do conteúdo ser jornalismo.

2. Praticar jornalismo independente e não hegemônico (não ligado a grandes oligopólios de comunicação ou partidos políticos).

3. Ter mais de $\mathbf{1 0 0}$ mil seguidores no Facebook.

4. Usar as redes sociais para disseminar conteúdo.

5. Ter grande parte das pautas relacionadas com o tema direitos humanos.

6. Posicionar-se explicitamente a favor dos direitos humanos.

7. Disponibilizar todo conteúdo de forma gratuita.

8. Aceitar responder ao questionário de pesquisa.

9. Contribuir para a construção de uma amostra diversa de veículos.

10. Ser de conhecimento prévio da pesquisadora.

Fonte: A autora, 2020.

\section{Revista ALTERJOR}

Grupo de Estudos Alterjor: Jornalismo Popular e Alternativo (ECA-USP)

Ano 12 - Volume 01 - Edição 25 - Janeiro-Junho de 2022

Av. Professor Lúcio Martins Rodrigues, 443, Cidade Universitária, São Paulo, CEP: 05508-020 
A partir desses critérios, entre os veículos contatados ${ }^{2}$, quatro aceitaram responder o questionário e participar da pesquisa: Ponte Jornalismo, Voz das Comunidades, Jornalistas Livres e The Intercept Brasil. A seguir, fazemos uma apresentação de cada um deles.

\section{Ponte Jornalismo}

Criada em 2014 por um grupo de jornalistas ${ }^{3}$ insatisfeitos com a cobertura de segurança pública realizada pelos veículos de imprensa tradicionais, a Ponte Jornalismo é uma organização sem fins lucrativos, que busca defender os direitos humanos por meio do jornalismo. Segundo o veículo, seu principal objetivo é "ampliar as vozes marginalizadas pelas opressões de classe, raça e gênero e promover a aproximação entre diferentes atores das áreas de segurança pública e justiça, colaborando na sobrevivência da democracia brasileira." (PONTE JORNALISMO, 2020).

Entre os assuntos cobertos pela Ponte, e que compõem os direitos humanos, os principais deles estão ligados à segurança pública, à justiça e ao aparelho repressivo do Estado. Tudo isso considerando as intersecções com raça, gênero e classe, posto que essas são questões centrais para a construção de uma sociedade democrática. Sendo assim, são temas comuns do veículo: violência de estado (denúncias de violações cometidas pelas forças de segurança contra as populações negras e pobres); raça (luta contra o racismo em suas diferentes formas); gênero (pautas relacionadas às mulheres, à população LGBTQIA+ e à opressão do patriarcado); e cultura (produção cultural e artística relacionada a outras temáticas).

No site da Ponte (ponte.org), é possível encontrar ainda uma relação de 11 princípios norteadores das ações dos profissionais envolvidos no projeto. São eles: defesa dos direitos humanos; jornalismo de causa; ampliação de vozes; trabalho sem fins lucrativos, profissional e sustentável; jornalismo preciso; defesa dos oprimidos; apartidarismo; democracia interna; jornalismo construtor de pontes; jornalismo de impacto; e valorização de vidas e corpos humanos.

\footnotetext{
${ }^{2}$ Convidados que não retornaram a tempo de participar da pesquisa: Mídia Ninja, Agência Pública, Alma Preta e Catarinas. Veículo que recusou participar: Revista AzMina.

${ }^{3}$ Fundadores da Ponte Jornalismo: André Caramante, Bruno Paes Manso, Caio Palazzo, Claudia Belfort, Fausto Salvadori Filho, Joana Brasileiro, Laura Capriglione, Luís Adorno, Maria Carolina Trevisan, Marina Amaral, Milton Bellintani, Natalia Viana, Paulo Eduardo Dias, Tatiana Merlino, Rafael Bonifácio e William Cardoso.
}

\section{Revista ALTERJOR}

Grupo de Estudos Alterjor: Jornalismo Popular e Alternativo (ECA-USP)

Ano 12 - Volume 01 - Edição 25 - Janeiro-Junho de 2022 


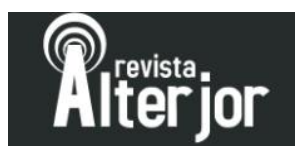

Com um vasto acervo de reportagens denunciando violações por parte do Estado e da Justiça, a Ponte já sofreu diversos ataques e censuras. Alguns exemplos são a acusação de um porta-voz da Polícia Militar de que a equipe do veículo recebia dinheiro do crime organizado e a agressão sofrida pelo repórter fotográfico Daniel Arroyo, atingido por uma bala de borracha e detido ilegalmente durante uma cobertura. Além disso, o repórter Arthur Stabile e o diretor de redação Fausto Salvadori passaram por revistas ilegais e o veículo enfrentou episódios de censura judicial, como quando um vídeo em que uma promotora caluniou o coletivo Mães de Maio foi proibido de ser publicado, ou quando entrevistas com presos foram vetadas e uma reportagem foi obrigada a não citar os nomes de seus entrevistados.

Denunciando prisões ilegais e outras violações por parte do Estado e da Justiça, a Ponte já recebeu diversos prêmios por suas reportagens, como o Prêmio Vladimir Herzog, que reconhece ações no campo dos direitos humanos. Em pouco tempo, o veículo passou a ocupar um espaço de referência em comunidades e coletivos, principalmente no estado de São Paulo, que encontram uma forma alternativa de dar voz às suas denúncias e, em alguns casos, conseguir justiça ${ }^{4}$.

Assim como grande parte da mídia alternativa no Brasil, conforme aponta o Mapa do Jornalismo Independente (AGÊNCIA PÚBLICA, 2019), a Ponte Jornalismo encontrou dificuldades para se sustentar financeiramente, principalmente no começo. Em seus três primeiros anos de atuação, a equipe trabalhou voluntariamente. Em 2017, com o lançamento de uma campanha de financiamento coletivo que arrecadou $\mathrm{R} \$ 74.689,00$, o veículo começou a caminhar em direção à profissionalização e à sustentabilidade e, em 2018, passou a contar com uma equipe remunerada trabalhando em período integral.

Além dos recursos do financiamento coletivo, a Ponte recebeu doações de fundações privadas, como a Open Society Foundations e a Repórteres Sem Fronteiras. Atualmente, a iniciativa continua se mantendo com doações de leitores e fundações privadas, além da venda de conteúdos e serviços para parceiros, como o Yahoo News.

\footnotetext{
${ }^{4}$ No site da Ponte, é possível encontrar a seção "Impactos", dedicada aos casos em que reportagens do veículo agiram positivamente na libertação de inocentes presos e no afastamento de criminosos do Estado. Disponível em: <https://ponte.org/sobre/impactos/>. Acesso em: 28 jan. 2021. Lista da equipe completa em: <https://ponte.org/sobre/autores/>. Acesso em: 30 jan. 2021.
}

\section{Revista ALTERJOR}

Grupo de Estudos Alterjor: Jornalismo Popular e Alternativo (ECA-USP)

Ano 12 - Volume 01 - Edição 25 - Janeiro-Junho de 2022 


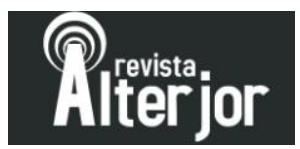

\section{Voz das Comunidades}

Um menino de 11 anos, morador do Morro do Adeus, na Zona Norte do Rio de Janeiro, decide criar um jornal para falar dos assuntos relacionados à sua comunidade. A história do Voz das Comunidades começa assim, ainda em 2005. O menino era Rene Silva dos Santos, então aluno da Escola Municipal Alcides de Gasperi, no bairro de Higienópolis. A ideia de criar o Voz surgiu depois que ele participou, durante três meses, de um jornal que já existia em sua escola, organizado pelos alunos do grêmio estudantil. Ao desenvolver o trabalho no ambiente escolar, Rene passou a observar problemas sociais que antes não via e a fazer paralelos entre a escola e a comunidade em que vivia.

A partir disso, com o apoio de professoras e da diretora da escola, Rene fundou o Voz da Comunidade, ainda no singular, para mostrar a realidade e os verdadeiros problemas sociais enfrentados diariamente pelos moradores da comunidade do Morro do Adeus, umas das 13 que compõem o Complexo do Alemão. Cinco anos mais tarde, em 2010, quando o Alemão foi ocupado pela polícia e pelo exército, Rene resolveu narrar em tempo real, por meio do Twitter, tudo o que acontecia na comunidade. Foi aí que a iniciativa começou a atrair mais público e a ser percebida, inclusive, pela mídia tradicional brasileira e internacional, fazendo a história de Renan com o Voz ganhar notoriedade ${ }^{5}$.

Atualmente, funcionando como organização não-governamental, o Voz da Comunidades ampliou sua cobertura para cerca de 15 comunidades no Rio, ganhou portal na internet (vozdascomunidades.com.br) e aplicativo para smartphone. Após um ano e cinco meses fora de circulação, a versão impressa do jornal voltou a ser publicada em janeiro de 2021, com uma tiragem de 10 mil exemplares distribuídos gratuitamente no Complexo do Alemão e da Penha. O jornal continua sendo uma iniciativa comunitária e funciona com o trabalho voluntário de uma equipe de mais de trinta profissionais ${ }^{6}$, entre jornalistas, fotógrafos, designers e produtores.

Além da produção jornalística, a ONG mantém projetos e campanhas sociais, como a Pandemia com Empatia, em que são recolhidas doações para compra e distribuição de água, alimentos e produtos de higiene pessoal, e o Prato das Comunidades, que recolhe recursos para

\footnotetext{
${ }^{5}$ Em 2013, a história de Rene com o Voz das Comunidades fez parte do enredo da telenovela Salve Jorge, exibida pela Rede Globo.

${ }^{6}$ Rene Silva (editor-chefe), Renato Moura (chefe de redação), Melissa Cannabrava (coordenadora de jornalismo), Jonnas di Andrade (coordenador do portal), Gracilene Firmino (responsável pelo jornal impresso). Lista da equipe completa em: 〈https://www.vozdascomunidades.com.br/equipe/>. Acesso em: 28 jan. 2021.
}

\section{Revista ALTERJOR}

Grupo de Estudos Alterjor: Jornalismo Popular e Alternativo (ECA-USP)

Ano 12 - Volume 01 - Edição 25 - Janeiro-Junho de 2022 Av. Professor Lúcio Martins Rodrigues, 443, Cidade Universitária, São Paulo, CEP: 05508-020 


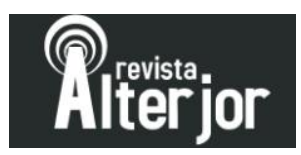

compra de refeições já prontas, preparadas e entregues aos moradores por restaurantes e mototaxistas da própria comunidade - uma tentativa para movimentar também a economia local.

\section{Jornalistas Livres}

Em março de 2015, quando as manifestações pelo impeachment da ex-presidenta Dilma Rousseff aconteciam em diversos estados do Brasil, um grupo de comunicadores, jornalistas, ativistas, fotógrafos e videomakers ${ }^{7}$ se uniu com o objetivo de contrapor uma narrativa de ódio e antidemocrática, que parecia ganhar força nas ruas e nos grandes meios de comunicação. Fazendo uma cobertura, em tempo real, com repórteres que estavam nas ruas em meio aos manifestantes, os Jornalistas Livres logo chamaram a atenção do público e ganharam milhares de seguidores no Facebook, principal canal usado para transmissão das informações na época.

Criado nesse contexto, desde o início, os Jornalistas Livres se colocam em oposição à tradicional indústria jornalística e deixam claro ao público que buscam distanciamento de conceitos historicamente enraizados no jornalismo, como neutralidade, isenção e apartidarismo. Em manifesto disponibilizado no site em que são publicados seus conteúdos (jornalistaslivres.org), o veículo destaca essa posição contrária ao que chama de "mídia tradicional centralizada e centralizadora." (JORNALISTAS LIVRES, 2021). Para embasar tal posicionamento, autodefine-se como uma rede de coletivos originada na diversidade, cujos valores que os unem são o amor pela democracia e a defesa radical dos direitos humanos.

A luta pela democratização da comunicação, a humanização do jornalismo, o combate ao preconceito de qualquer origem, bem como à desigualdade social e à discriminação racial também são citados como pilares da ação do veículo. Além disso, os Jornalistas Livres enaltecem o senso de coletividade em sua atuação, afirmando trabalhar de forma colaborativa em todos seus processos, sem nenhum tipo de competitividade entre os membros da equipe.

Apesar de manterem sede física na cidade de São Paulo, trabalhando de forma voluntária e colaborativa, os Jornalistas Livres fazem coberturas e produzem reportagens sobre assuntos envolvendo outras localidades. Para funcionar, assim como a Ponte, o veículo lançou

\footnotetext{
${ }^{7}$ Entre os profissionais fundadores dos Jornalistas Livres, estão: Laura Capriglione, Carolina Trevisan, Pedro Alexandre Sanches, Larissa Gould, Louise Akemi, Bia Abramo, Aroldo Ceravolo, Rafael Vilela, Victor Amatucci, Eliane Dias, Vinicius Souza e Adriano Diogo.
}

\section{Revista ALTERJOR}

Grupo de Estudos Alterjor: Jornalismo Popular e Alternativo (ECA-USP)

Ano 12 - Volume 01 - Edição 25 - Janeiro-Junho de 2022 
inicialmente uma campanha de financiamento coletivo no site Catarse ${ }^{8}$, que atingiu $132 \%$ da meta, arrecadando R $\$ 132.730,00$. Com os recursos, o grupo pôde investir na criação da sede em São Paulo, na construção do site, na compra de equipamentos básicos e passagens para coberturas jornalísticas em outras cidades.

\section{The Intercept Brasil}

Autodefinindo-se como uma agência de notícias cujo principal objetivo é responsabilizar poderosos por meio de um jornalismo destemido e combativo, o The Intercept Brasil realiza investigações e análises sobre temas como política, corrupção, meio ambiente, tecnologia e mídia. Braço do site estadunidense The Intercept, criado em 2014, a versão brasileira foi lançada em agosto de 2016.

No artigo em que anuncia a criação do site brasileiro, o jornalista Glenn Greenwald ${ }^{9}$, fundador do projeto em ambos os países, destaca alguns dos principais acontecimentos que corroboraram para a iniciativa. Entre eles, a crise política agravada pelo processo de impeachment da ex-presidenta Dilma Rousseff e a ação de grandes veículos de comunicação no país, que "mascaram os principais desafios sociais e econômicos presentes, assim como a diversidade de opiniões e movimentos existentes no país." (GREENWALD, 2016). Além disso, Greenwald ressalta o monopólio da comunicação no Brasil que, como já visto, é comandada há muito tempo pelas mesmas cinco famílias. Essa homogeneidade da mídia brasileira, segundo ele, é uma ameaça à democracia e à liberdade de imprensa.

Nesse sentido, os dois principais objetivos do veículo ao iniciar os trabalhos no Brasil eram: ampliar o reconhecimento do país pelo mundo e disponibilizar uma plataforma para que jornalistas e escritores brasileiros pudessem compartilhar informações sobre questões políticas, econômicas e sociais envolvendo o local onde vivem. O The Intercept Brasil afirma dar a esses profissionais a liberdade editorial e o suporte legal para expor a corrupção, a injustiça e o que mais for necessário.

\footnotetext{
${ }^{8}$ Campanha disponível em: < https://www.catarse.me/jornalistaslivres>. Acesso em: 30 jan. 2021.

${ }^{9}$ Glenn Greenwald é jornalista, escritor e advogado constitucionalista dos Estados Unidos. Ganhou o Prêmio Pulitzer de Jornalismo em 2014 pela reportagem sobre o programa de espionagem da NSA. Fundou o The Intercept com Laura Poitras e Jeremy Scahill. Em outubro de 2020, anunciou sua saída do veículo, alegando ter sido impedido de criticar Joe Biden. A lista da equipe completa da versão brasileira do site está disponível em: https://theintercept.com/brasil/staff/>. Acesso em: 1 fev. 2021.
}

\section{Revista ALTERJOR}

Grupo de Estudos Alterjor: Jornalismo Popular e Alternativo (ECA-USP)

Ano 12 - Volume 01 - Edição 25 - Janeiro-Junho de 2022 


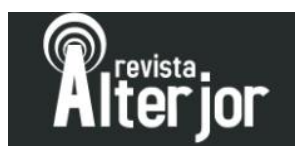

Assim como os demais veículos participantes desta pesquisa, o The Intercept Brasil garante funcionar de forma independente. $\mathrm{O}$ site, tanto o estadunidense quanto a versão brasileira, é publicado pela First Look Media, uma organização fundada por Pierre Omidyar, criador do eBay e filantropo, para apoiar iniciativas originais e independentes no jornalismo.

$\mathrm{O}$ veículo também mantém uma seção de financiamento recorrente aberta ao público, em que os leitores podem escolher o quanto desejam doar para a manutenção do site. A doação pode ser única, mensal ou anual e, a partir de um valor específico, são disponibilizadas recompensas: um curso de segurança digital ( $\mathrm{R} \$ 600$ ou $\mathrm{R} \$ 50$ mensais) ou um livro autografado (R\$ 1200 ou R\$100 mensais).

\section{Procedimentos metodológicos}

Elemento indispensável de qualquer pesquisa, principalmente a científica, a metodologia determina os procedimentos sistemáticos e racionais a serem seguidos ao longo do caminho para se atingir os objetivos pré-estabelecidos, respondendo às questões "como?", "com quê?", “onde?” e "quanto?". Contudo, é importante lembrar que não existe uma receita definida quando se trata de metodologia científica. O que há são aspectos teóricos e princípios que orientam a prática com processos e métodos, pois "um assunto tão complexo como a criação científica não seria suscetível de tal redução.” (GIL, 2002, p. 15).

Para o tratamento dos dados coletados, tanto das publicações quanto do questionário, optou-se pela análise de conteúdo qualitativa. Segundo Gil (2002), o aparecimento dessa técnica foi determinado justamente pela necessidade de interpretar o grande volume de material produzido pelos meios de comunicação, pois possibilita a descrição do conteúdo expresso pelas comunicações, permitindo exames para a identificação da ideologia implícita nas notícias de um jornal, por exemplo.

O autor explica o que é necessário para o desenvolvimento desse tipo de análise:

A análise de conteúdo desenvolve-se em três fases. A primeira é a pré-análise, onde se procede à escolha dos documentos, à formulação de hipóteses e à preparação do material para análise. A segunda é a exploração do material, que envolve a escolha das unidades, a enumeração e a classificação. A terceira etapa, por fim, é constituída pelo tratamento, inferência e interpretação dos dados. (GIL, 2002, p. 89).

Revista ALTERJOR

Grupo de Estudos Alterjor: Jornalismo Popular e Alternativo (ECA-USP)

Ano 12 - Volume 01 - Edição 25 - Janeiro-Junho de 2022

Av. Professor Lúcio Martins Rodrigues, 443, Cidade Universitária, São Paulo, CEP: 05508-020 


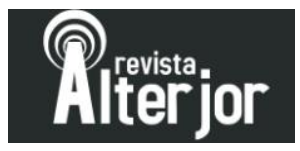

As pontuações do autor usam como referência o método formulado por Laurence Bardin (2016), uma das principais teóricas da área. As teorizações apresentadas por ela servirão como base para a análise dos dados coletados nesta pesquisa, conforme veremos mais adiante.

No que diz respeito à classificação, o estudo apresentado neste artigo tem caráter exploratório. Isso porque esse tipo de pesquisa, segundo Gil (2002), proporciona uma maior familiaridade com o problema, buscando torná-lo mais explícito, e tem como principal objetivo aprimorar ideias ou descobrir intuições. Seu planejamento também é bastante flexível, permitindo que sejam considerados os mais variados aspectos relativos ao fato estudado.

Além disso, geralmente, as pesquisas exploratórias envolvem: “(a) levantamento bibliográfico; (b) entrevistas com pessoas que tiveram experiências práticas com o problema pesquisado; e (c) análise de exemplos que 'estimulem a compreensão'." (Selltiz et al. apud GIL, 2002, p. 41). Tais ações estão em conformidade com o que é proposto aqui, visto que nosso objetivo é compreender como o conteúdo produzido e as estratégias utilizadas pela mídia alternativa contribuem na defesa e promoção dos direitos humanos e que, para isso, são estudados alguns veículos específicos representantes de tal mídia.

Nesse sentido, a abordagem escolhida é qualitativa, pois esse tipo de estudo evita números e lida com interpretações das realidades sociais (BAUER et al., 2002). Em outras palavras: "na pesquisa qualitativa a preocupação do pesquisador não é com a representatividade numérica do grupo pesquisado, mas com o aprofundamento da compreensão de um grupo social, de uma organização, de uma instituição, de uma trajetória etc." (GOLDENBERG, 2004, p.14). É isso que se busca compreender em relação a atuação da mídia alternativa e seu envolvimento com os direitos humanos.

Diante disso, a coleta de dados desta pesquisa está dividida em duas etapas. A primeira delas consiste na coleta de informações sobre os veículos participantes do estudo. Para tanto, foi utilizado um questionário pré-elaborado, com 12 questões abertas e fechadas, cujo objetivo era descobrir as estratégias utilizadas pelos veículos para disseminar seus conteúdos e o seu posicionamento em relação aos direitos humanos e à democratização da comunicação.

Para elaborar e distribuir o questionário aos participantes da pesquisa - uma pessoa de cada veículo estudado - foi utilizado o Google Forms, ferramenta fornecida pela Google para elaboração de formulários on-line. Tal ferramenta também foi o meio para aplicação do Termo de Consentimento Livre e Esclarecido (TCLE), que precede o questionário. Nele, constaram as

Revista ALTERJOR

Grupo de Estudos Alterjor: Jornalismo Popular e Alternativo (ECA-USP)

Ano 12 - Volume 01 - Edição 25 - Janeiro-Junho de 2022

Av. Professor Lúcio Martins Rodrigues, 443, Cidade Universitária, São Paulo, CEP: 05508-020 


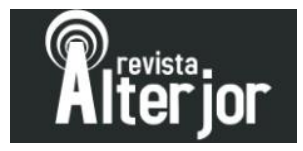

instruções necessárias, a proposta da pesquisa e a identificação da pesquisadora e da instituição representada.

O questionário foi enviado via e-mail aos participantes. Ao recebê-lo, o participante deveria acessar o link disponível na mensagem para ser direcionado ao questionário, ler e concordar com as condições do TCLE e, em seguida, responder às questões. As perguntas deveriam ser respondidas, preferencialmente, de acordo com o posicionamento do veículo que a pessoa representa e não segundo suas convicções individuais. Ao terminar, cada participante clicou em um botão que acionou o envio automático das informações para a pesquisadora.

Responderam ao questionário os seguintes profissionais representantes dos veículos participantes da pesquisa: Laura Capriglione (Jornalistas Livres), Arthur Stabile (Ponte Jornalismo), Rafael Moro Martins (The Intercept Brasil) e Neila de Oliveira Marinho (Voz das Comunidades).

A segunda etapa na coleta de dados foi a realização de uma pesquisa documental para levantar parte do material disponível nas páginas do Facebook de cada veículo pesquisado. O Facebook foi escolhido por se tratar de uma das redes sociais mais utilizadas pelos brasileiros atualmente (atrás apenas do YouTube ${ }^{10}$ ) e também por ser a rede social dos participantes com o maior número de seguidores.

A princípio, foram levantadas todas as publicações realizadas de agosto a outubro de 2020. As publicações foram organizadas em uma tabela, trazendo o link para cada post, seu assunto, formato (card, foto, link para matéria em site, vídeo, live etc.), bem como o número de interações (reações, comentários e compartilhamentos) e o engajamento (soma das interações).

A tabela 1 a seguir mostra a quantidade de publicações em cada veículo durante esses três meses.

\footnotetext{
${ }^{10}$ Dados do relatório Digital in 2020, levantamento realizado pela We Are Social em parceria com a Hootsuite. Disponível em: <https://datareportal.com/reports/digital-2020-brazil >. Acesso em: 23 fev. 2021.
}

\section{Revista ALTERJOR}

Grupo de Estudos Alterjor: Jornalismo Popular e Alternativo (ECA-USP)

Ano 12 - Volume 01 - Edição 25 - Janeiro-Junho de 2022 


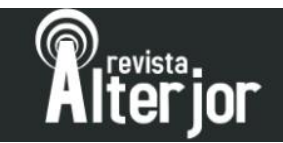

Tabela 1 - Quantidade de publicações no Facebook

\begin{tabular}{|c|c|c|c|c|}
\hline VEÍCULO & AGOSTO & SETEMBRO & OUTUBRO & TOTAL \\
\hline PONTE JORNALISMO & 61 & 132 & 149 & 342 \\
\hline VOZ DAS COMUNIDADES & 51 & 98 & 182 & 331 \\
\hline JORNALISTAS LIVRES & 75 & 93 & 519 & 687 \\
\hline THE INTERCEPT BRASIL & 102 & 91 & 86 & 279 \\
\hline
\end{tabular}

Fonte: A autora, 2020.

Após esse levantamento inicial, foram selecionadas 5\% dessas publicações para serem analisadas, a partir das categorias que serão apresentadas mais à frente, na seção de análise de resultados. Tal porcentagem foi determinada com a intencionalidade de estabelecer uma amostra viável de ser analisada nesta pesquisa, mas que permanecesse proporcional à quantidade de publicações de cada participante durante os três meses observados, posto que eles têm frequência de postagem distintas.

O critério escolhido para selecionar as publicações foi o índice de engajamento que, conforme vimos, é a soma da quantidade de reações ${ }^{11}$, comentários e compartilhamentos. Assim, o número de posts analisados corresponde a 5\% das publicações, de cada participante, que mais engajaram sua respectiva audiência no Facebook de agosto a outubro de 2020.

\section{Resultados}

A seguir, são apresentados os dados coletados nas duas etapas da pesquisa, por meio do questionário e da pesquisa documental no Facebook. A fim de simplificar a identificação dos participantes da pesquisa, são empregadas as seguintes siglas e abreviações: PJ (Ponte Jornalismo), VC (Voz das Comunidades), JL (Jornalistas Livres), TIB (The Intercept Brasil), Arthur (Arthur Stabile), Neila (Neila de Oliveira Marinho), Laura (Laura Capriglione) e Rafael (Rafael Moro Martins).

\footnotetext{
${ }^{11}$ As reações são as ações realizadas pelos usuários a partir dos botões "Curtir”, “Amei”, "Haha”, "Uau”, "Triste" e "Grr", disponíveis em cada publicação no Facebook.
}

\section{Revista ALTERJOR}

Grupo de Estudos Alterjor: Jornalismo Popular e Alternativo (ECA-USP)

Ano 12 - Volume 01 - Edição 25 - Janeiro-Junho de 2022 


\section{Questionário: a pauta dos direitos humanos e as estratégias de comunicação}

Após a leitura e aceitação do TCLE, a primeira pergunta do questionário pedia aos participantes que informassem seu nome, veículo para qual trabalham e cargo nele exercido. Depois disso, os sujeitos de direitos começavam a responder aos questionamentos relacionados ao tema da pesquisa. Na sequência, destacam-se os resultados obtidos com as questões objetivas (múltiplas escolhas).

Conforme ilustra a figura 1 a seguir, todos os participantes atribuíram a máxima importância aos direitos humanos.

Figura 1 - A importância dos direitos humanos para o veículo

2. Qual a importância dos direitos humanos para o veículo em que você trabalha? Marque de 1 a 10 , sendo 1 o menos importante e 10 o mais importante.

4 respostas

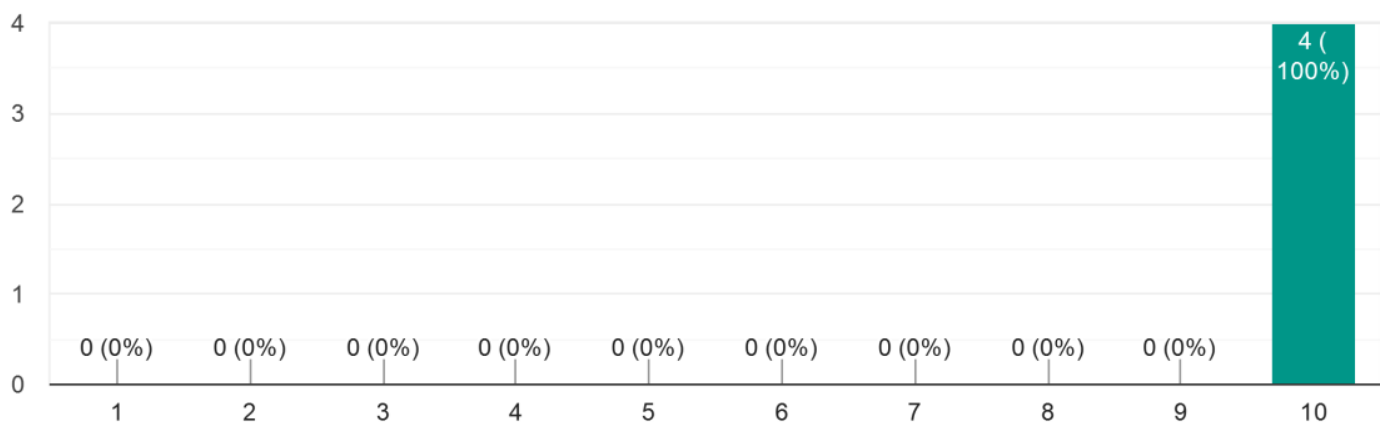

Fonte: A autora, Google Forms, 2020.

$\mathrm{Na}$ sequência, a grande maioria diz abordar pautas relacionadas aos direitos humanos diariamente. A única exceção é o TIB, cujo representante ressaltou que o veículo não trabalha com hard news, ou seja, a frequência das postagens não é um fator determinante em sua atuação.

\section{Revista ALTERJOR}

Grupo de Estudos Alterjor: Jornalismo Popular e Alternativo (ECA-USP)

Ano 12 - Volume 01 - Edição 25 - Janeiro-Junho de 2022

Av. Professor Lúcio Martins Rodrigues, 443, Cidade Universitária, São Paulo, CEP: 05508-020 


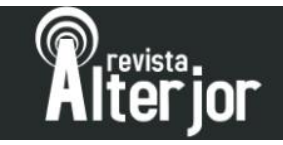

Figura 2 - Frequência da abordagem de pautas sobre direitos humanos

3. Com que frequência são abordadas pautas relacionadas aos direitos humanos? 4 respostas

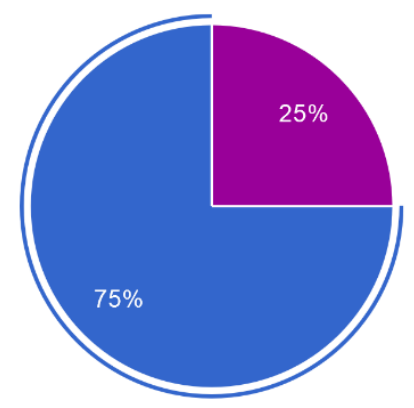

Todos os dias

Semanalmente

Quinzenalmente

Mensalmente

Não somos um veículo de hard news

Fonte: A autora, Google Forms, 2020.

Além disso, todos os veículos apontaram o racismo como sendo o tema, relacionado aos direitos humanos, mais presente nos conteúdos produzidos (Figura 3).

Figura 3 - Temas de direitos humanos mais abordados

4. Quais dos temas abaixo são mais presentes nos conteúdos produzidos pelo veiculo que você representa? Enumere de 1 a 5 , sendo 10 menos frequente e 5 o mais frequente.
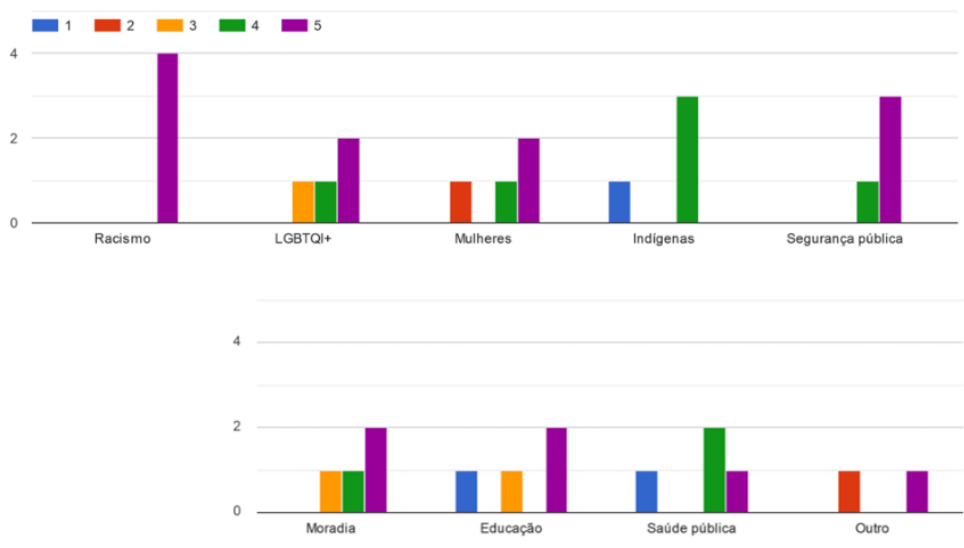

Fonte: A autora, Google Forms, 2020.

A tabela 2 a seguir oferece uma melhor visualização dos cinco temas mais votados pelos participantes da pesquisa.

\section{Revista ALTERJOR}

Grupo de Estudos Alterjor: Jornalismo Popular e Alternativo (ECA-USP)

Ano 12 - Volume 01 - Edição 25 - Janeiro-Junho de 2022

Av. Professor Lúcio Martins Rodrigues, 443, Cidade Universitária, São Paulo, CEP: 05508-020 


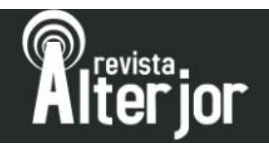

Tabela 2 - Questionário: temas mais abordados

\begin{tabular}{ll}
\hline \multicolumn{1}{c}{ Tema } & $\%$ \\
\hline Racismo & $100 \%$ \\
Segurança pública & $95 \%$ \\
LGBTQI+ & $85 \%$ \\
Moradia & $85 \%$ \\
Mulheres & $80 \%$ \\
\hline
\end{tabular}

Fonte: A autora, 2021.

Sobre a principal estratégia adotada para a divulgar e distribuir os conteúdos produzidos, todos os participantes informaram se tratar da realização de posts orgânicos (sem investimento financeiro) em redes sociais, conforme demonstra a figura 4.

Figura 4 - Estratégias de divulgação de conteúdos

7. Quais as estratégias adotadas para a divulgação e distribuição dos conteúdos?

4 respostas

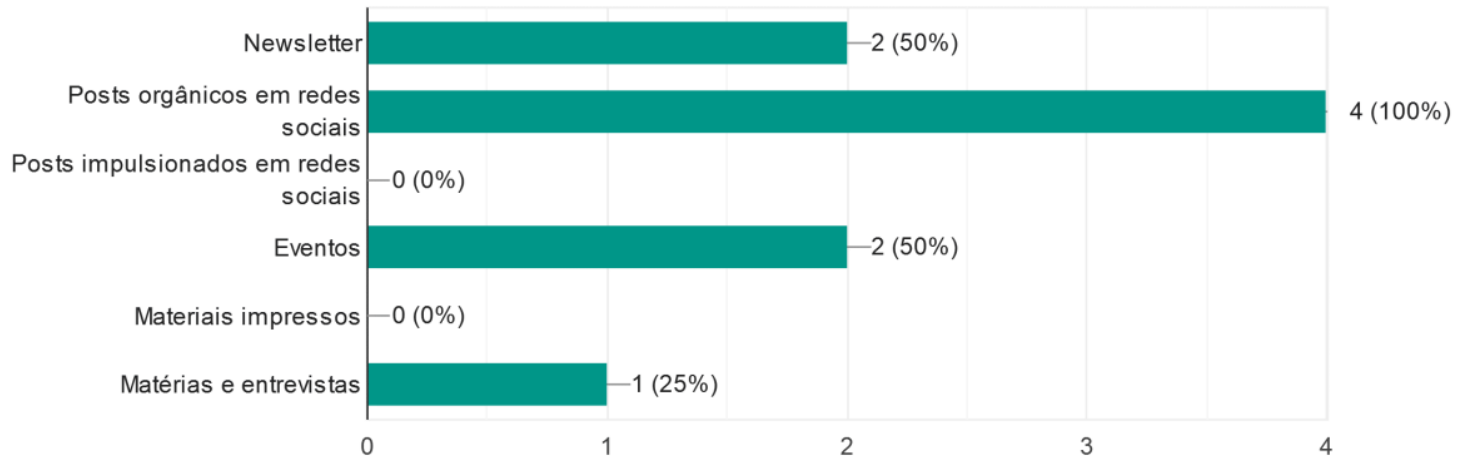

Fonte: A autora, Google Forms, 2020.

Já quando questionados a respeito das fontes de recursos para a manutenção dos veículos, todos os participantes responderam que utilizam o financiamento coletivo. Metade deles afirmou utilizar também recursos recebidos por meio de participação em editais e de doações de instituições privadas.

\section{Revista ALTERJOR}

Grupo de Estudos Alterjor: Jornalismo Popular e Alternativo (ECA-USP)

Ano 12 - Volume 01 - Edição 25 - Janeiro-Junho de 2022

Av. Professor Lúcio Martins Rodrigues, 443, Cidade Universitária, São Paulo, CEP: 05508-020 


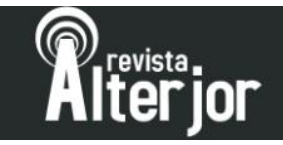

Figura 5 - Fontes de recursos para manutenção do veículo

8. Como são obtidos recursos para a manutenção do veículo?

4 respostas

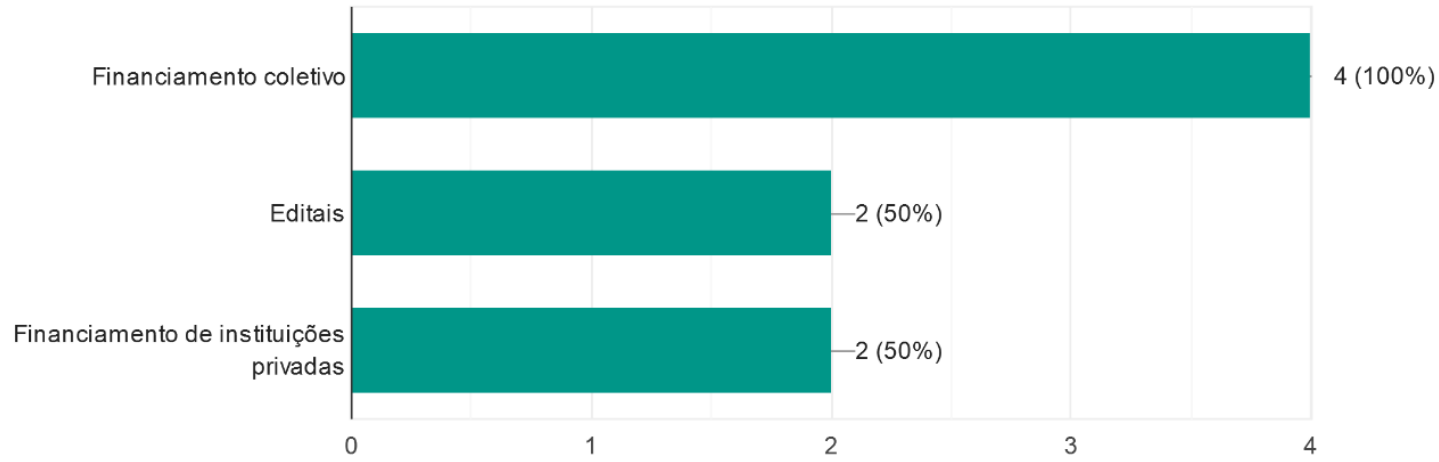

Fonte: A autora, Google Forms, 2020.

Chegando nas questões abertas, foi possível saber mais a respeito da participação da sociedade civil nos veículos pesquisados. Ao menos metade deles participa de outras formas de organização civis, como coletivos, fóruns e frentes. Os JL, segundo Laura, integram o Fórum Nacional pela Democratização da Comunicação (FNDC). Já o VC, junto com Coletivo Papo Reto e Mulheres em Ação no Alemão, fundaram o Gabinete de Crise do Complexo do Alemão $^{12}$, uma iniciativa que reuniu ativistas do Complexo do Alemão para arrecadar recursos e auxiliar as famílias da comunidade prejudicadas durante a pandemia de Covid-19. Além disso, todos os veículos afirmaram que a sociedade participa, de algum modo, da produção dos conteúdos publicados. Três deles deixaram claro que o público contribui por meio da indicação de pautas.

As últimas quatro perguntas do questionário tinham intenção de obter respostas menos diretas e mais elaboradas, que transmitissem as percepções dos participantes a respeito dos desafios encontrados para a prática da mídia alternativa no Brasil e a influência da atual conjuntura do país nesse sentido. Ao serem questionados sobre a comunicação ser considerada um direito humano, todos transpareceram corroborar com tal visão. Válido destacar aqui, no entanto, que o participante Rafael, colaborador do TIB, ressaltou estar respondendo a essa pergunta a partir de uma opinião pessoal, que pode ou não ser compartilhada pelo veículo: "Por

\footnotetext{
${ }^{12}$ Até julho de 2020, 45 mil pessoas já haviam sido ajudadas por ações do Gabinete de Crise do Complexo do Alemão. Disponível em:< https://bit.ly/3tjxBru>. Acesso em: 1 fev. 2021.
}

\section{Revista ALTERJOR}

Grupo de Estudos Alterjor: Jornalismo Popular e Alternativo (ECA-USP)

Ano 12 - Volume 01 - Edição 25 - Janeiro-Junho de 2022 
mim, o que posso dizer é que uma sociedade bem informada tende a ter mais consciência de seus próprios direitos" (Rafael/TIB).

Já os JL e a PJ responderam, respectivamente, que a comunicação: "permite visibilizar os grupos vulneráveis, valorizar sua cultura, sua vida, defender seus direitos, vocalizar suas reivindicações" (Laura/JL) e que é "essencial. Para a plena existência de direitos, o direito de se comunicar, se informar e cobrar respostas através da imprensa surge como elemento básico para a concretização dos direitos humanos." (Arthur/PJ).

Neila, do VC, mencionou o direito à liberdade de expressão e a ação da mídia no combate a atitudes e crimes que violam direitos humanos: "Somos um veículo que fala de favela para favela, com tudo, entendemos que o direito a liberdade de expressão deve ser respeitada e pautada sempre no combate ao racismo, preconceito e intolerância." (Neila/VC).

$\mathrm{Na}$ décima pergunta, cujo objetivo era identificar os maiores desafios na prática do jornalismo independente no Brasil, a falta de recursos financeiros e estruturais foi citada por metade dos participantes. Laura/JL destacou a dificuldade de financiamento para grandes reportagens e Arthur/PJ citou a falta de estrutura:

Veículos de renome apresentam capacidade maior de equipe e equipamento do que os veículos independentes. Sem tantos recursos para a contratação de equipes similares às de veículos da dita grande imprensa, essa surge como uma das barreiras para conseguir, com eficiência e sem sugar de quem está na equipe, fazer um trabalho de nível esperado. (Arthur/PJ).

Neila/VC e Rafael/TIB forneceram respostas distintas. Enquanto ela respondeu que o desafio está em controlar o fluxo de informações e apurar os acontecimentos para fortalecer a credibilidade do veículo, ele apontou o governo como principal obstáculo:

O jornalismo independente contribui para a formação de um espaço democrático. Entretanto, precismos ficar atentos a quantidade de informações e sobretudo na sua apuração, pois a base de todo e qualquer informação deve ser pautada na verdade. Visamos muito a credibilidade do nosso trabalho, e isso é fundamental. (Neila/VC).

Um governo hostil à imprensa. (Rafael/TIB).

A penúltima pergunta do questionário indagava o que é necessário para tornar real a democratização da comunicação no Brasil. Neila/VC disse que é preciso respeitar o "senso crítico de cada um" e que todos "exerçam de forma participativa sua cidadania". Rafael/TIB afirmou que para democratizar a comunicação é necessário que se produza um jornalismo "de

\section{Revista ALTERJOR}

Grupo de Estudos Alterjor: Jornalismo Popular e Alternativo (ECA-USP)

Ano 12 - Volume 01 - Edição 25 - Janeiro-Junho de 2022 
boa qualidade" e que seja capaz de alcançar um público "que vá além da classe média e média alta."

Já os outros dois participantes forneceram respostas mais elaboradas, citando exemplos que poderiam ser seguidos no Brasil:

Em primeiro lugar, cumprir a lei: Igrejas e políticos não podem ser proprietários de emissoras de televisão, mas são. Depois, é preciso proibir a propriedade cruzada de meios de comunicação, como nos EUA. Também é necessário criar contrapartidas reais a serem cumpridas por quem recebe uma concessão de TV e Rádio, como a produção de x horas de programação dedicada à educação e à cultura. Acrescento que seria fundamental a instituição de um imposto sobre a venda de TVs que permitisse o financiamento de uma emissora pública de jornalismo e documentários de qualidade, como é a BBC. E, por fim, seria fundamental estabelecer critérios de representatividade regional, racial, social, educacional e cultural, visando à concessão de canais de TV... (Laura/JL).

Uma lei de meios, como proposto na Argentina, seria interessante. Apesar de não ter sido implementada por interesses de veículos hegemônicos, o texto da proposta apresentava alternativas interessantes para não haver controles quase plenos de grupos X ou Y sobre a comunicação de um país. No Brasil é comum vermos famílias com poderio financeiro dominando os meios de comunicação de certas localidades. $\mathrm{O}$ que é prejudicial à democracia. (Arthur/PJ).

Como último questionamento, os participantes foram convidados a deixar sua avaliação sobre a atual conjuntura brasileira, do ponto de vista econômico, político e social. Além disso, foram questionados sobre qual seria o papel da mídia nesse contexto. Essa foi a questão em que todos deixaram respostas mais longas, se comparadas às perguntas anteriores. Rafael/TIB destacou novamente estar fornecendo uma opinião pessoal, ou seja, que não necessariamente é a mesma do veículo para o qual trabalha.

As respostas foram as seguintes:

Jornalistas Livres opõem-se editorialmente ao atual governo federal porque defendemos os Direitos Humanos, a Democracia e os direitos sociais e trabalhistas. Para nós, o papel da mídia é impedir a naturalização da violência, do desrespeito aos direitos, da destruição do meio ambiente. Nosso propósito usar o jornalismo como ferramenta contra a barbárie. (Laura/JL).

Essa discussão envolve muitos fatores éticos e morais, e o atual cenário político do Brasil não é favorável em nenhum dos três poderes. O que vemos

\section{Revista ALTERJOR}

Grupo de Estudos Alterjor: Jornalismo Popular e Alternativo (ECA-USP)

Ano 12 - Volume 01 - Edição 25 - Janeiro-Junho de 2022 
é um total descaso e banalização do governo com sua população, e neste momento em que atravessamos uma crise mundial com a pandemia, toda essa desordem ficou bem clara. A mídia por sua vez tem o dever de noticiar a verdade e com responsabilidades, pois é importante restabelecer o pensamento social e crítico, visando o interesse público. (Neila/VC).

Novamente, não posso falar pelo veículo, pois o Intercept tem jornalistas com posições individuais e independentes. Mas creio que há um consenso entre nós de que vivemos a mais grave crise da democracia desde 1985, além de uma crise econômica sem precedentes (devida principalmente à pandemia, mas não apenas) que aprofunda nossa já imensa desigualdade social. O papel da mídia é escancarar as causas da crise, além de abrir espaço para vozes que proponham caminhos para superá-la. (Rafael/TIB).

Falando por mim, vejo o momento como complexo. As questões e turbulências político-econômicas geram problemas sociais que, a médio e longo prazo, tem a perspectiva de piora acentuada. Assim, vejo o lado social como o mais impactado pela pandemia de coronavírus, somadas as mortes decorrentes da falta de ação pública para controlar a pandemia com as omissões quanto a proteção social. Falar em R\$ 600 como garantidor de direitos, sobrevivência ou o que quer que seja é um absurdo. (Arthur/PJ).

Refletiremos sobre cada uma das respostas mais adiante, na seção de análise de resultados.

\section{Publicações no Facebook: significado dos conteúdos}

Diante do total de posts publicados nas páginas no Facebook dos veículos participantes da pesquisa, como mencionado anteriormente, optou-se por realizar o recorte de uma amostra com os $5 \%$ de posts com o maior engajamento (soma de interações), no período selecionado de três meses (agosto a outubro de 2020). Dessa forma, 81 publicações participaram da análise, sendo 17 da Ponte Jornalismo, 17 do Voz das Comunidades, 34 dos Jornalistas Livres e 14 do The Intercept Brasil, conforme apresentam os quadros 2, 3, 4 e 5 abaixo.

Quadro 2 - Publicações com mais engajamento: Ponte Jornalismo

\begin{tabular}{|l|l|l|l|r|r|r|r|}
\hline Class. & Mês & Assunto & Formato & Reações & Coment. & Compart. & Engajamento \\
\hline $\mathbf{1}$ & Set. & Jovem é morto pela PM & Matéria & 432 & 186 & 972 & 1590 \\
\hline $\mathbf{2}$ & Out. & Corte internacional decide que polícia & Matéria & 523 & 104 & 811 & 1438 \\
\hline
\end{tabular}

\section{Revista ALTERJOR}

Grupo de Estudos Alterjor: Jornalismo Popular e Alternativo (ECA-USP)

Ano 12 - Volume 01 - Edição 25 - Janeiro-Junho de 2022 


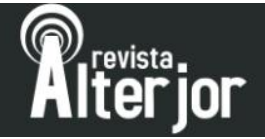

\begin{tabular}{|c|c|c|c|c|c|c|c|}
\hline & & não pode enquadrar sem motivo & & & & & \\
\hline 3 & Set. & $\begin{array}{l}\text { Músico negro preso injustamente é } \\
\text { libertado }\end{array}$ & Matéria & 679 & 17 & 458 & 1154 \\
\hline 4 & Ago. & $\begin{array}{l}\text { Racismo de homem branco contra } \\
\text { motoboy negro }\end{array}$ & Vídeo & 450 & 231 & 276 & 957 \\
\hline 5 & Set. & PM preso com drogas & Matéria & 494 & 48 & 345 & 887 \\
\hline 6 & Out. & PM mata menino adormecido & Matéria & 340 & 97 & 446 & 883 \\
\hline 7 & Set. & PM agride homem imobilizado & Matéria & 492 & 127 & 178 & 797 \\
\hline 8 & Ago. & $\begin{array}{l}\text { Comunidades comemoram decisão do } \\
\text { STF de proibir operações policiais }\end{array}$ & Matéria & 440 & 169 & 119 & 728 \\
\hline 9 & Out. & PM segue turistas negros & Matéria & 384 & 50 & 277 & 711 \\
\hline 10 & Ago. & $\begin{array}{l}\text { Pesquisa mostra que PM ama } \\
\text { Bolsonaro e odeia LGBTs }\end{array}$ & Matéria & 420 & 38 & 242 & 700 \\
\hline 11 & Out. & Assassinatos da Rota & Matéria & 257 & 159 & 249 & 665 \\
\hline 12 & Out. & $\begin{array}{l}\text { Casal denuncia racismo no Extra e é } \\
\text { ignorado pela PM }\end{array}$ & Matéria & 471 & 42 & 151 & 664 \\
\hline 13 & Set. & Prisão ilegal de jovem negro & Matéria & 435 & 36 & 193 & 664 \\
\hline 14 & Ago. & $\begin{array}{l}\text { PM agride mestre de capoeira com filho } \\
\text { no colo }\end{array}$ & Matéria & 403 & 37 & 194 & 634 \\
\hline 15 & Set. & Padre Julio Lancelotti recebe ameaças & Matéria & 363 & 36 & 190 & 589 \\
\hline 16 & Out. & AlfaCon escola de métodos de tortura & Matéria & 325 & 125 & 127 & 577 \\
\hline 17 & Out. & Bancada da bala & Matéria & 348 & 18 & 203 & 569 \\
\hline
\end{tabular}

Fonte: PONTE JORNALISMO, 2020.

A diferença no total de publicações da Ponte Jornalismo e do Voz das Comunidades foi pequena (apenas 11 posts). Por isso, os dois veículos terão a mesma quantidade de publicações participando da análise de conteúdo (5\% arrendondado para mais).

Quadro 3 - Publicações com mais engajamento: Voz das Comunidades

\begin{tabular}{|c|c|c|c|c|c|c|c|}
\hline Class. & Mês & Assunto & Formato & Reações & Coment. & Compart. & Engajamento \\
\hline 1 & Out. & $\begin{array}{l}\text { Morre fotógrafo Felipe Paiva, do } \\
\text { Vidigal }\end{array}$ & Matéria & 13000 & 478 & 530 & 14008 \\
\hline 2 & Out. & $\begin{array}{l}\text { Rede Atacadão abre vagas para pessoas } \\
\text { sem experiência }\end{array}$ & Matéria & 3600 & 1100 & 3800 & 8500 \\
\hline 3 & Set. & $\begin{array}{l}1 \text { ano do assassinato de Agatha Vitória } \\
\text { no Alemão }\end{array}$ & Imagem & 966 & 22 & 220 & 1208 \\
\hline 4 & Out. & Criação de avatar & Texto & 195 & 527 & 4 & 726 \\
\hline 5 & Out. & $\begin{array}{l}\text { Pesquisa candidatos a vereador no } \\
\text { Alemão }\end{array}$ & Imagem & 154 & 441 & 17 & 612 \\
\hline
\end{tabular}

\section{Revista ALTERJOR}

Grupo de Estudos Alterjor: Jornalismo Popular e Alternativo (ECA-USP)

Ano 12 - Volume 01 - Edição 25 - Janeiro-Junho de 2022

Av. Professor Lúcio Martins Rodrigues, 443, Cidade Universitária, São Paulo, CEP: 05508-020 


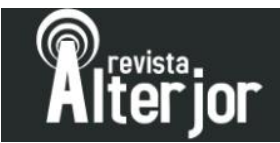

\begin{tabular}{|c|c|c|c|c|c|c|c|}
\hline 6 & Out. & Funk carioca & Compart. & 393 & 20 & 178 & 591 \\
\hline 7 & Out. & $\begin{array}{l}\text { Jovem morre com bala perdida no } \\
\text { Morro da Coroa }\end{array}$ & Matéria & 445 & 46 & 53 & 544 \\
\hline 8 & Out. & $\begin{array}{l}\text { Gravação Poesia Acústica } 10 \text { na Vila } \\
\text { Cruzeiro }\end{array}$ & Matéria & 288 & 48 & 189 & 525 \\
\hline 9 & Set. & $\begin{array}{l}\text { Bronzeamento artificial no Complexo } \\
\text { do Alemão }\end{array}$ & Vídeo & 334 & 103 & 64 & 501 \\
\hline 10 & Out. & Intenção de voto no Rio & Texto & 136 & 360 & 4 & 500 \\
\hline 11 & Out. & Eleições 2020: Almir Napoleão & Matéria & 190 & 174 & 76 & 440 \\
\hline 12 & Out. & $\begin{array}{l}\text { Advogada tira dúvidas sobre auxílio } \\
\text { emergencial }\end{array}$ & Vídeo & 198 & 162 & 71 & 431 \\
\hline 13 & Out. & Jovem baleado no Complexo da Penha & Vídeo & 323 & 51 & 40 & 414 \\
\hline 14 & Out. & Outubro Rosa & Matéria & 230 & 105 & 72 & 407 \\
\hline 15 & Out. & $\begin{array}{l}\text { Vendedora de doces é sucesso no } \\
\text { Complexo da Penha }\end{array}$ & Matéria & 333 & 14 & 57 & 404 \\
\hline 16 & Set. & Projeto Penha Solidária & Vídeo & 131 & 66 & 176 & 373 \\
\hline 17 & Set. & $\begin{array}{l}\text { Jovem baleado no Complexo da Penha é } \\
\text { detido }\end{array}$ & Vídeo & 191 & 121 & 36 & 348 \\
\hline
\end{tabular}

Fonte: VOZ DAS COMUNIDADES, 2020.

Os Jornalistas Livres são o veículo com a maior quantidade de publicações a serem analisadas, visto que publicaram mais do que o dobro de posts que os outros participantes da pesquisa.

Quadro 4 - Publicações com mais engajamento: Jornalistas Livres

\begin{tabular}{|l|r|l|r|r|r|r|r|}
\hline Class. & Mês & Assunto & Formato & Reações & Coment. & Compart. Engajamento \\
\hline $\mathbf{1}$ & Set. & Lula fala ao Brasil & Vídeo & 18000 & 28000 & 10000 & 56000 \\
\hline $\mathbf{2}$ & Out. & Bolsonaro contra vacina & Imagem & 6800 & 453 & 16000 & 23253 \\
\hline $\mathbf{3}$ & Out. & Eleições bolivianas & Imagem & 14000 & 1200 & 2100 & 17300 \\
\hline $\mathbf{4}$ & Out. & Robinho e estupro & Imagem & 9400 & 1000 & 2200 & 12600 \\
\hline $\mathbf{5}$ & Set. & $\begin{array}{l}\text { Lula em solidariedade ao Padre Julio } \\
\text { Lancelotti }\end{array}$ & Vídeo & 6700 & 3000 & 2800 & 12500 \\
\hline $\mathbf{6}$ & Out. & $\begin{array}{l}\text { Renúncia de Pepe Mujica, ex-presidente } \\
\text { do Uruguai }\end{array}$ & Imagem & 10000 & 443 & 1700 & 12143 \\
\hline $\mathbf{7}$ & Out. & Governantes e abuso do povo brasileiro & Imagem & 5300 & 1700 & 3800 & 10800 \\
\hline $\mathbf{8}$ & Out. & Bolsonaro e vacina chinesa & Imagem & 5700 & 607 & 3900 & 10207 \\
\hline $\mathbf{9}$ & Out. & Brasileiros contra a vacina & Imagem & 5900 & 318 & 3800 & 10018 \\
\hline $\mathbf{1 0}$ & Out. & Chile derruba constituição de Pinochet & Imagem & 6800 & 2200 & 544 & 9544 \\
\hline
\end{tabular}

\section{Revista ALTERJOR}

Grupo de Estudos Alterjor: Jornalismo Popular e Alternativo (ECA-USP)

Ano 12 - Volume 01 - Edição 25 - Janeiro-Junho de 2022

Av. Professor Lúcio Martins Rodrigues, 443, Cidade Universitária, São Paulo, CEP: 05508-020 


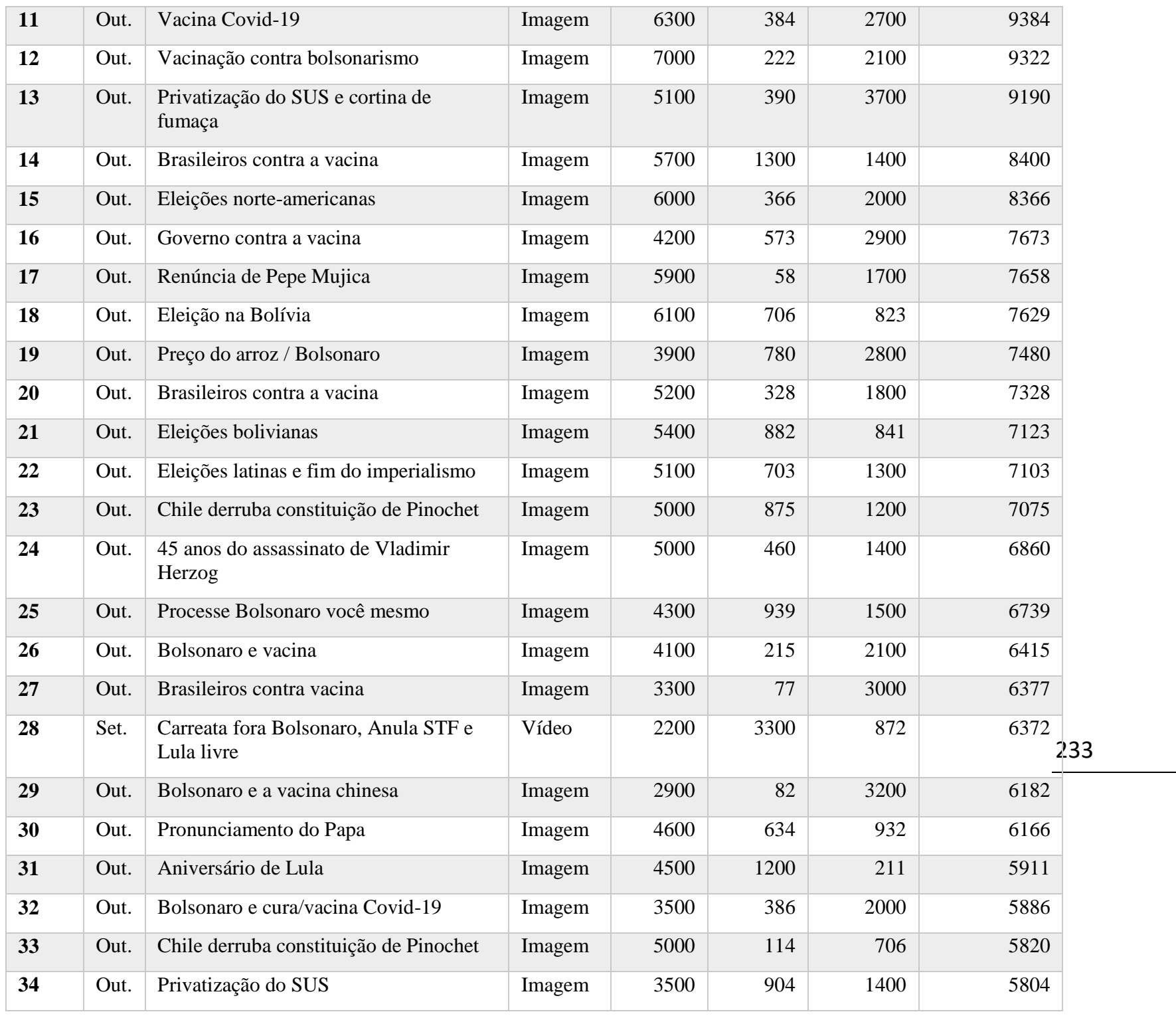

Fonte: JORNALISTAS LIVRES, 2020.

O The Intercept Brasil é o que menos publicou durante o período analisado. Portanto, é o veículo com o menor número de publicações a serem analisadas.

Quadro 5 - Publicações com mais engajamento: The Intercept Brasil

\begin{tabular}{|c|c|c|c|c|c|c|c|}
\hline Class. & Mês & Assunto & Formato & Reações & Coment. & Compart. & Engajamento \\
\hline 1 & Set. & $\begin{array}{l}\text { Glenn Greenwald explica } \\
\text { Brasil de Bolsonaro }\end{array}$ & Vídeo & 15000 & 5600 & 12000 & 32600 \\
\hline 2 & Set. & Queimadas no Pantanal & Vídeo & 5000 & 502 & 12000 & 17502 \\
\hline
\end{tabular}

\section{Revista ALTERJOR}

Grupo de Estudos Alterjor: Jornalismo Popular e Alternativo (ECA-USP)

Ano 12 - Volume 01 - Edição 25 - Janeiro-Junho de 2022

Av. Professor Lúcio Martins Rodrigues, 443, Cidade Universitária, São Paulo, CEP: 05508-020 


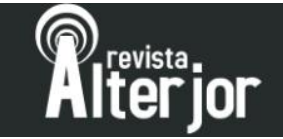

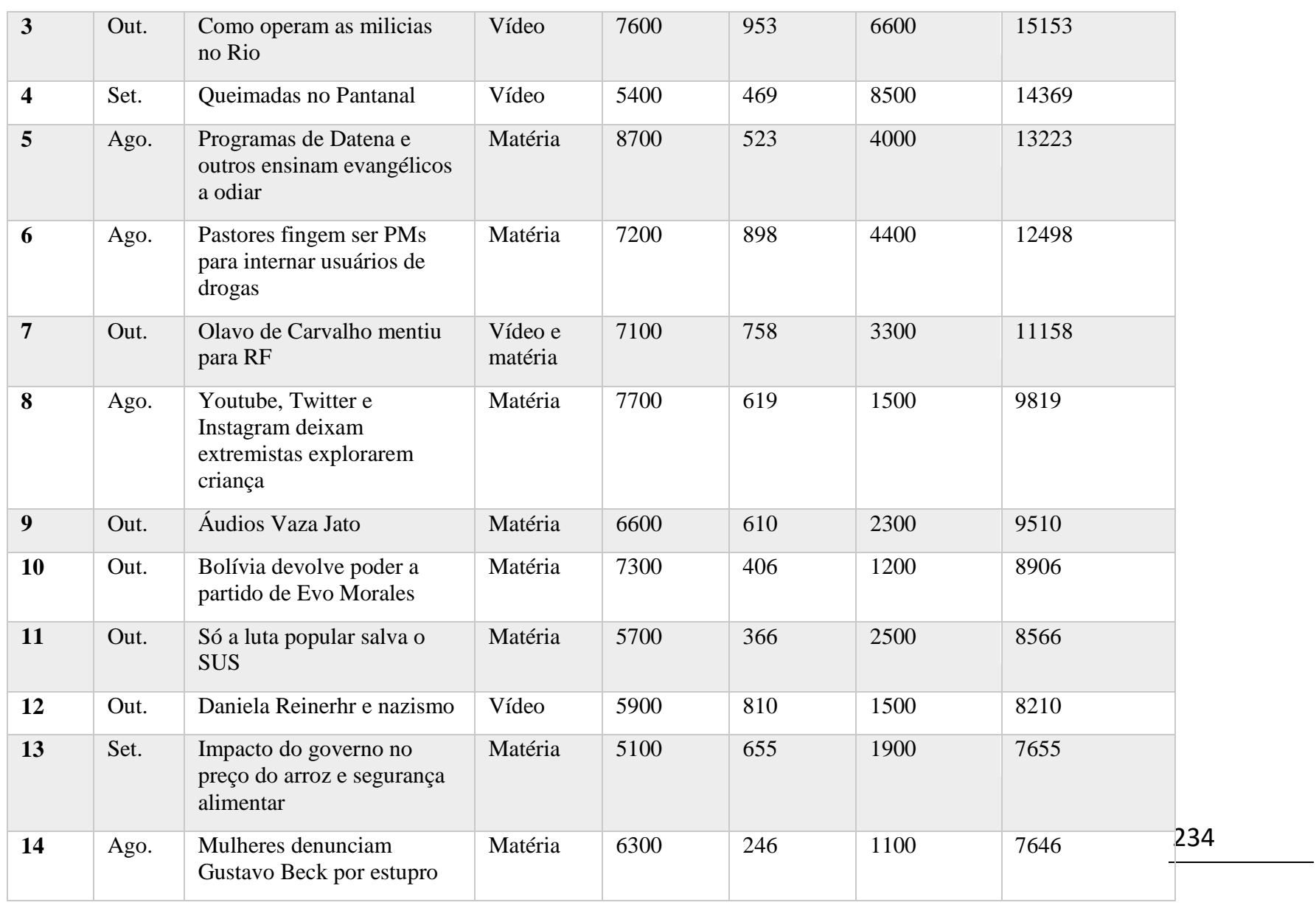

Fonte: THE INTERCEPT BRASIL, 2020.

\section{Análise dos resultados: a democratização da comunicação em direitos humanos}

Antes de analisarmos as publicações selecionadas, é preciso resgatar alguns dados importantes levantados por meio do questionário. Dessa forma, poderemos relacioná-los aos resultados coletados pelas publicações. O primeiro ponto a se destacar é que $100 \%$ dos participantes atribuiu a importância máxima aos direitos humanos, sob a ótica do veículo que representam, e 75\% deles afirmaram publicar conteúdos relacionados diariamente.

Ainda nas respostas às questões objetivas, foi possível identificar um consenso entre os participantes sobre o tema de direitos humanos abordado com mais frequência: o racismo. Tal informação não surpreende se pensarmos a questão social envolvendo a população negra no Brasil, historicamente à margem e submetida a todos os tipos de violações. Nesse contexto, o aparecimento do item segurança pública em segundo lugar na lista de temas mais abordados pode indicar uma relação indireta com o primeiro.

\section{Revista ALTERJOR}

Grupo de Estudos Alterjor: Jornalismo Popular e Alternativo (ECA-USP)

Ano 12 - Volume 01 - Edição 25 - Janeiro-Junho de 2022 


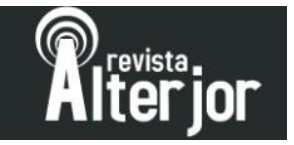

Sobre as estratégias para divulgação dos conteúdos e manutenção do veículo, também houve unanimidade entre os participantes, visto que $100 \%$ deles responderam recorrer a posts orgânicos em redes sociais e ao financiamento coletivo. Importante destacar os 50\% que indicaram editais e instituições privadas como outras fontes de recursos e doações financeiras. Isso evidencia a lacuna existente no que diz respeito a incentivos públicos destinados à mídia alternativa, que, desamparada, pode colocar sua independência em risco ao aceitar recursos de empresas privadas. Esse é mais um dos aspectos que exaltam a importância da democratização da comunicação para a subsistência desses veículos.

Diante disso, já era esperado que nenhum dos participantes se declarasse contrário à afirmação da comunicação como um direito humano, o que se confirmou na primeira pergunta subjetiva do questionário. Afinal, quando a comunicação não é tratada como um produto à serviço do capital, ela se aproxima de se ser o que se espera que seja: um direito. Mesmo que para tanto veículos como os pesquisados tenham que transformar sua ação em um ato de resistência, sem ter certeza se continuarão existindo no futuro próximo.

Para classificar as respostas às últimas três perguntas abertas, recorrendo a um exemplo "clássico e muito conhecido de análise de conteúdo" (BARDIN, 2016, p.65), foram criados três parâmetros principais, pensados a partir da informação solicitada na questão: 1) desafios; 2) soluções para a democratização da comunicação; e 3) posicionamento em relação ao governo federal. A partir dessa proposta, foi possível chegar aos seguintes resultados: no primeiro parâmetro, as respostas mencionam como desafios a falta de recursos financeiros e estruturais (50\%), o processo de apuração devido ao fluxo intenso de informações $(25 \%)$ e um governo hostil à imprensa (25\%).

Como soluções para a democratizar a comunicação, foram sugeridas a proibição da propriedade cruzada de meios de comunicação (50\%), o desenvolvimento de uma lei para regulamentar a prática $(25 \%)$, a criação de um imposto para o financiamento de uma emissora pública (25\%), bem como o estabelecimento de critérios de representatividade em canais de TV (25\%). Também foram citadas a produção de jornalismo de boa qualidade e capaz de alcançar públicos diversos (25\%), o respeito ao senso crítico de cada cidadão (25\%) e o exercício da cidadania participativa $(25 \%)$.

Importante ressaltar diante das soluções apontadas que a maior parte delas depende da ação de um Estado preocupado com o impacto do monopólio da comunicação no país e sua falta de diversidade, algo que não parece estar na agenda dos governantes atuais. Nesse sentido, os veículos pesquisados confirmam a hipótese de que, como vimos no capítulo anterior, a mídia

\section{Revista ALTERJOR}

Grupo de Estudos Alterjor: Jornalismo Popular e Alternativo (ECA-USP)

Ano 12 - Volume 01 - Edição 25 - Janeiro-Junho de 2022

Av. Professor Lúcio Martins Rodrigues, 443, Cidade Universitária, São Paulo, CEP: 05508-020 


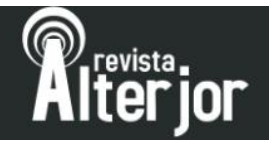

alternativa nasce como um movimento de resistência ao autoritarismo, declarando-se contrários ao governo de Jair Bolsonaro. Tal oposição fica clara na utilização, pelos participantes, das expressões: "naturalização da violência", "desrespeito aos direitos", "destruição do meio ambiente", "barbárie", "descaso e banalização", "mais grave crise da democracia desde 1985", "crise econômica sem precedentes", "imensa desigualdade social", "turbulências políticoeconômicas", "problemas sociais", “omissões", "absurdo", entre outras.

Diante disso tudo, então, partimos para a análise dos dados coletados na segunda etapa desta pesquisa. Seguindo os passos apontados por Bardin (2016), a partir da leitura do material coletado nas publicações, foram identificadas duas dimensões norteadoras (parâmetros) para a realização da análise de conteúdo. São elas: a temática (sobre o que são as pautas relacionadas aos direitos humanos) e a abordagem (aspectos técnicos e de valor observados nos conteúdos). A temática é o mais simples de se identificar, pois basta a leitura da publicação para verificar se o assunto em questão se relaciona ou não com os direitos humanos e, em caso positivo, apontar seu tema. Analisando a lista de publicações de cada veículo participante da pesquisa, foi possível realizar essa classificação, que resultou no levantamento de 13 temáticas.

O quadro 6 abaixo apresenta a lista de temáticas, bem como exemplos de assuntos encontrados que se encaixam em cada uma delas.

Quadro 6 - Descrição das temáticas

\begin{tabular}{|l|l|}
\hline Temática & Exemplos de assuntos \\
\hline Cultura & Eleições, direitos e deveres. \\
\hline Infância e juventude & Religião, crenças, apresentações artísticas. \\
\hline LGBTQI+ & Direitos da criança e do adolescente. \\
\hline Meio ambiente & Sexualidade, identidade de gênero, homofobia, transfobia. \\
\hline Moradia & Queimadas no Pantanal. \\
\hline Mulheres & Comunidades periféricas, ocupações, saneamento básico. \\
\hline Pessoas com deficiência & Igualdade salarial, empreendedorismo feminino, violência doméstica. \\
\hline Política & Discursos de personalidades políticas, manifestações. \\
\hline Racismo & Preconceito, genocídio da população negra. \\
\hline Saúde pública & Pandemia de Covid-19, auxílio emergencial, vacinação. \\
\hline
\end{tabular}

\section{Revista ALTERJOR}

Grupo de Estudos Alterjor: Jornalismo Popular e Alternativo (ECA-USP)

Ano 12 - Volume 01 - Edição 25 - Janeiro-Junho de 2022 


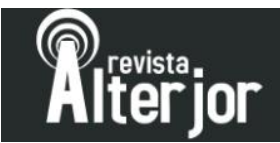

Segurança alimentar

Segurança pública
Alimentação, água, preços dos alimentos.

Ações da polícia, homicídios, roubos, violência.

Fonte: A autora, 2021.

Já para compreender a abordagem, foram estabelecidas seis características (categorias) a serem identificadas nas publicações: o formato, a extensão ou quantidade, o engajamento, as fontes consultadas, o posicionamento em relação ao assunto abordado e o tratamento (tipo) do conteúdo publicado. O quadro 7 a seguir apresenta cada uma das características, bem como sua definição ou definições de suas subdivisões.

Quadro 7 - Descrição das características de abordagem analisadas

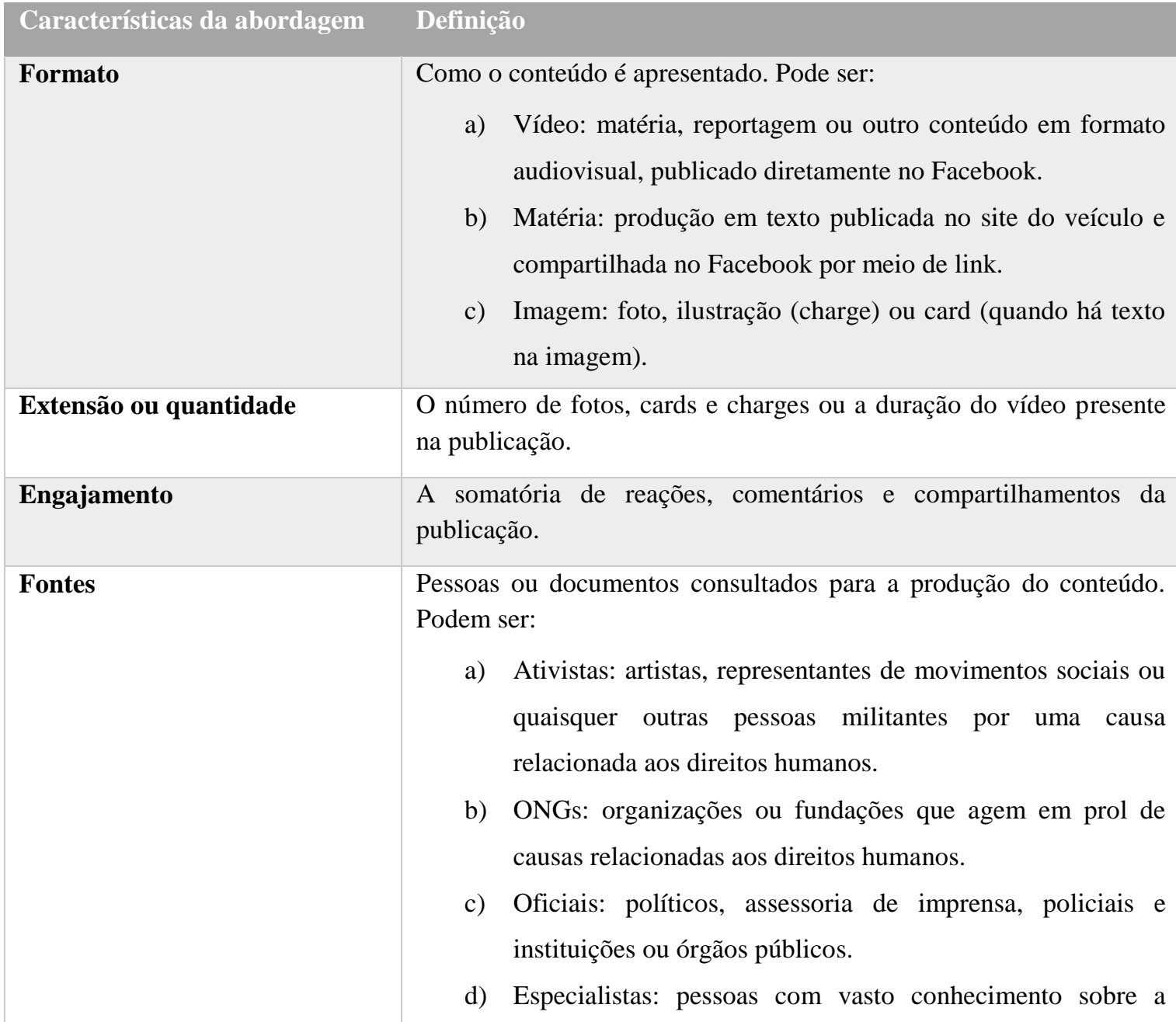

\section{Revista ALTERJOR}

Grupo de Estudos Alterjor: Jornalismo Popular e Alternativo (ECA-USP)

Ano 12 - Volume 01 - Edição 25 - Janeiro-Junho de 2022 


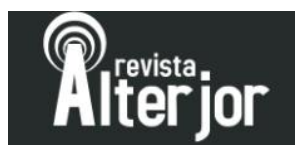

\begin{tabular}{|c|c|c|}
\hline & e) & $\begin{array}{l}\text { pauta tratada. } \\
\text { População: moradores de determinada região ou qualquer } \\
\text { outra pessoa participante da sociedade civil. }\end{array}$ \\
\hline Posicionamento & \multicolumn{2}{|c|}{$\begin{array}{l}\text { A posição do veículo em relação ao assunto ou acontecimento } \\
\text { abordado em seu conteúdo. Esse posicionamento pode estar implícito } \\
\text { ou explícito e é observado a partir de ideologia, tom de voz, fontes } \\
\text { ouvidas, adjetivos utilizados para descrever determinado assunto, } \\
\text { acontecimento ou pessoa, entre outras características. A fim de } \\
\text { classificação, esse posicionamento pode ser: favorável ou contrário. }\end{array}$} \\
\hline Tratamento & $\begin{array}{l}\text { Elemen } \\
\text { produzi } \\
\text { classifi }\end{array}$ & $\begin{array}{l}\text { to criado nesta pesquisa para identificar o tipo de conteúdo } \\
\text { do pela mídia alternativa, de forma simples e direta. Nessa } \\
\text { Oção, as opções são: } \\
\text { Opinativo: quando o conteúdo apresenta de forma clara a } \\
\text { opinião do veículo ou seus colaboradores. } \\
\text { Informativo: quando não há a presença clara de opinião no } \\
\text { conteúdo, sendo priorizada a descrição de fatos. } \\
\text { Denúncia: conteúdo com a intenção de denunciar crimes ou } \\
\text { outras violações. } \\
\text { Serviço: notícia/informação sobre eventos, vagas de } \\
\text { emprego, apresentações culturais, inaugurações ou } \\
\text { quaisquer outros acontecimentos envolvendo a prestação de } \\
\text { serviços ao público. }\end{array}$ \\
\hline
\end{tabular}

Importante destacar aqui que a categorização dos conteúdos será feita a partir do que eles mais apresentam. Ou seja, não significa que uma publicação colocada em determinada categoria não possa ter elementos de outra. Por exemplo, um conteúdo pode ser informativo, mas apresentar claramente a opinião do veículo e, sendo assim, será classificado como opinativo.

Isso posto, a partir do estabelecimento das duas dimensões e da construção do sistema de categorias, foi possível então realizar a análise do conteúdo das publicações e sua classificação por meio da leitura cuidadosa de cada uma delas. Para melhor visualização dos dados, foi criado um quadro categorial de dupla entrada (BARDIN, 2016), disponível no quadro 8 na página seguinte. É partindo dele que poderemos identificar padrões e analisar resultados.

\section{Revista ALTERJOR}

Grupo de Estudos Alterjor: Jornalismo Popular e Alternativo (ECA-USP)

Ano 12 - Volume 01 - Edição 25 - Janeiro-Junho de 2022 


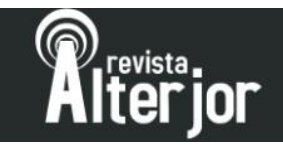

Quadro 8 - Resultados da análise: Temática x Abordagem
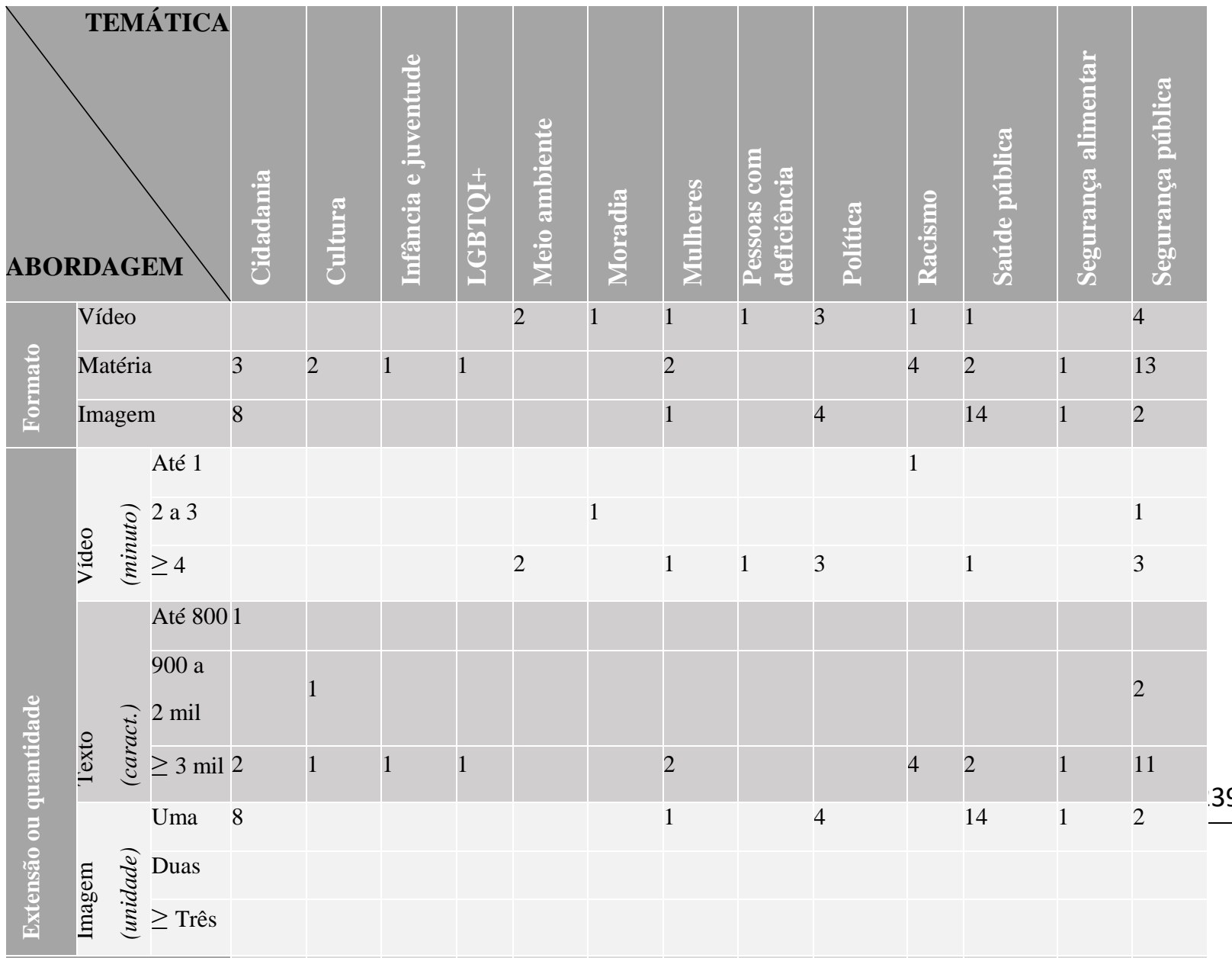

\begin{tabular}{|c|c|c|c|c|c|c|c|c|c|c|c|c|c|c|}
\hline \multicolumn{2}{|c|}{$\begin{array}{l}\text { Engajamento } \\
\text { (interações) }\end{array}$} & 72322 & 13748 & 9819 & 700 & 31871 & 12500 & 21151 & 373 & 127043 & 4150 & 134813 & 15153 & 54592 \\
\hline & Ativistas & 7 & & & & 2 & & 1 & & 4 & & 15 & 1 & 2 \\
\hline & ONGs & 1 & & & & & & & 1 & & & & & 1 \\
\hline & Oficiais & & 1 & 1 & & & 1 & & & 1 & & & & 7 \\
\hline 8 & Especialistas & 1 & 1 & & 1 & & & & & 2 & & 2 & 1 & 3 \\
\hline อิ & População & 2 & & & & & & 3 & & & 5 & & & 6 \\
\hline$\stackrel{\ominus}{=}$ & Favorável & 11 & 1 & & & & & 2 & 1 & 5 & & 4 & & 2 \\
\hline $\begin{array}{l}0 \\
\frac{0}{3} \\
: 3\end{array}$ & Contrário & & 1 & 1 & 1 & 2 & 1 & 2 & & 2 & 5 & 13 & 2 & 17 \\
\hline E & Opinativo & 7 & 1 & & & & & & & 6 & & 15 & 2 & 3 \\
\hline
\end{tabular}

\section{Revista ALTERJOR}

Grupo de Estudos Alterjor: Jornalismo Popular e Alternativo (ECA-USP)

Ano 12 - Volume 01 - Edição 25 - Janeiro-Junho de 2022

Av. Professor Lúcio Martins Rodrigues, 443, Cidade Universitária, São Paulo, CEP: 05508-020 
Informativo 3

Denúncia

Serviço
1
2

21
1

Fonte: A autora, 2021.

Das 81 publicações selecionadas, 73 têm relação com alguma temática direta ou indiretamente ligada aos direitos humanos. Observando os dados coletados na análise que podem ser visualizados no quadro de dupla entrada, é possível identificar as temáticas mais abordadas, bem como as que têm maior engajamento, o formato mais utilizado, a extensão/ quantidade, as fontes mais consultadas, o posicionamento do veículo em relação ao assunto abordado e o tratamento do conteúdo. O quadro 9 abaixo traz essas informações, considerando os três temas mais frequentes e os três elementos mais observados em cada categoria.

Quadro 9 - Resultados mais expressivos da análise de conteúdo

\begin{tabular}{|l|l|l|l|l|l|l|}
\hline Tema & Formato & $\begin{array}{l}\text { Extensão/ } \\
\text { quantidade }\end{array}$ & Engajamento & Fontes & Posicionamento & Tratamento \\
\hline $\begin{array}{l}\text { Segurança } \\
\text { pública } \\
(19)\end{array}$ & $\begin{array}{l}\text { Imagem } \\
(30)\end{array}$ & $\begin{array}{l}\text { Uma } \\
\text { imagem } \\
(30)\end{array}$ & $\begin{array}{l}\text { Saúde pública } \\
(134.813)\end{array}$ & $\begin{array}{l}\text { Ativistas } \\
(32)\end{array}$ & Contrário (47) & $\begin{array}{l}\text { Opinativo } \\
(34)\end{array}$ \\
\hline $\begin{array}{l}\text { Saúde } \\
\text { pública } \\
(17)\end{array}$ & $\begin{array}{l}\text { Matéria } \\
(29)\end{array}$ & $\begin{array}{l}\text { Texto com } \\
3 \text { mil } \\
\text { caracteres } \\
\text { ou mais }\end{array}$ & $\begin{array}{l}\text { Política } \\
(127.043)\end{array}$ & $\begin{array}{l}\text { População } \\
(16)\end{array}$ & Favorável (26) & $\begin{array}{l}\text { Denúncia } \\
(22)\end{array}$ \\
\hline $\begin{array}{l}\text { Cidadania } \\
(11)\end{array}$ & $\begin{array}{l}\text { Vídeos } \\
(14)\end{array}$ & $\begin{array}{l}\text { Vídeo com } \\
4 \text { minutos } \\
\text { ou mais }\end{array}$ & $\begin{array}{l}\text { Cidadania } \\
(72.322)\end{array}$ & $\begin{array}{l}\text { Oficiais e } \\
\text { especialistas } \\
(11 \text { cada) }\end{array}$ & & \\
\hline
\end{tabular}

Fonte: A autora, 2021.

Comparando os resultados da análise com os dados coletados por meio do questionário, notamos algumas divergências, mas que podem ser explicadas se considerarmos o recorte de tempo da pesquisa. Quando questionados sobre o tema relacionado aos direitos humanos mais abordado no veículo, todos os participantes assinalaram o racismo como o mais frequente.

\section{Revista ALTERJOR}

Grupo de Estudos Alterjor: Jornalismo Popular e Alternativo (ECA-USP)

Ano 12 - Volume 01 - Edição 25 - Janeiro-Junho de 2022 


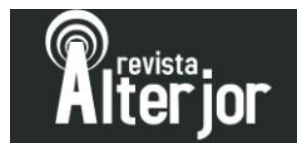

Contudo, ao olharmos os resultados da análise dos posts, percebemos que a temática com mais conteúdo é segurança pública, seguida por saúde pública e cidadania.

A presença do referido tema em primeiro lugar pode ser justificada por suas relações com o racismo e pela participação da Ponte Jornalismo na pesquisa. O veículo se apresenta como uma organização sem fins lucrativos cujo foco é justamente a abordagem de questões da área de segurança pública, sob a ótica dos direitos humanos. Das 17 publicações analisadas da Ponte, 11 eram sobre essa temática. Além disso, entre os conteúdos de segurança pública, muitas vezes, há a abordagem de assuntos envolvendo racismo, mesmo que esse não seja o tema central da matéria. Talvez essa seja uma das principais razões para que segurança pública apareça em primeiro lugar, enquanto racismo, apesar de apontado como o tema mais abordado no questionário, ocupa a quinta posição se considerados os dados da análise das publicações.

Já a indicação da temática saúde pública em segundo lugar na análise das publicações, provavelmente, é um reflexo da pandemia de Covid-19. Entre agosto e outubro de 2020, como não poderia deixar de ser, foram muitas as pautas sobre o assunto. Críticas às ações do Estado, ou à falta delas, boletins sobre o número de pessoas infectadas, esclarecimento de dúvidas sobre o auxílio emergencial, agravamento de problemas sociais históricos como a miséria e o desemprego. Tudo isso e mais foram foco de investigações e críticas por parte da mídia alternativa brasileira.

Também ligado a acontecimentos durante o período pesquisado, está o aparecimento da temática cidadania como a terceira mais abordada. Isso porque 2020 foi ano de eleições municipais no país, bem como de escolha de presidentes em países de relações importantes com o Brasil, como Bolívia e Estados Unidos. Além disso, houve plebiscito histórico no Chile em que a população decidiu acabar com a Constituição de Pinochet.

Ainda sobre as temáticas mais presentes nas publicações, podemos observar uma coerência considerável com os índices de engajamento: as quatro temáticas mais abordadas também são as quatro com maior número de interações, mesmo que em diferente ordem. Isso mostra que os conteúdos mais trabalhados pelos veículos estão alinhados aos interesses de seu público. No questionário, $75 \%$ dos participantes informaram que o público colabora com a sugestão de pautas, o que pode ser uma evidência desse resultado.

Já no que diz respeito ao formato preferido pelos veículos para suas produções, é importante ressaltar a mínima diferença entre os posts com imagem (30) e aqueles com link para

\section{Revista ALTERJOR}

Grupo de Estudos Alterjor: Jornalismo Popular e Alternativo (ECA-USP)

Ano 12 - Volume 01 - Edição 25 - Janeiro-Junho de 2022

Av. Professor Lúcio Martins Rodrigues, 443, Cidade Universitária, São Paulo, CEP: 05508-020 


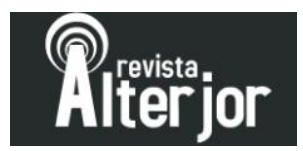

leitura da matéria em site próprio do veículo (29). Outro ponto que merece ser destacado aqui é o fato de que 25 dessas 30 publicações com imagem se referem a charges publicadas pelos Jornalistas Livres, um espaço cedido a ativistas para divulgarem seu trabalho. Esse formato satírico foi pouquíssimo ou nada utilizado nos meses de agosto e setembro de 2020, mas esteve presente diariamente em grande número no mês de outubro do mesmo ano, mostrando-se como os conteúdos mais geradores de reações, comentários e compartilhamentos. Como o critério para seleção da amostra de publicações foi o engajamento, esses conteúdos acabaram sendo os mais analisados.

Sendo assim, se pararmos para analisar qual foi o formato de publicação mais utilizado considerando os quatro veículos participantes da pesquisa, veremos que na realidade são as matérias. Com a exceção de um conteúdo do Voz das Comunidades, todas elas trazem textos com mais de 3 mil caracteres, o que mostra que a utilização desse gênero jornalístico pode estar mais associada à necessidade de explorar determinados assuntos de forma mais aprofundada. $\mathrm{O}$ mesmo acontece com os vídeos (gravações ou lives), que costumam ser longos com mais de quatro minutos e, em sua maioria, ligados às temáticas de segurança pública e política.

Nesse sentido, as três últimas categorias de análise têm o caráter qualitativo mais evidente. Por meio delas, conseguimos perceber que, conforme afirmaram todos os participantes no questionário, a sociedade civil participa significativamente na produção dos conteúdos. Evidência disso é encontrada em quase dois terços das publicações analisadas, que utilizam ativistas ou membros da população em geral como fontes principais para as informações. Contudo, é preciso destacar que essa representatividade da sociedade civil ainda tem muito espaço para crescer na mídia alternativa por meio da parceria entre esses veículos e outras organizações de movimentos sociais que lutam por direitos humanos, visto que apenas metade dos participantes (Jornalistas Livres e Voz das Comunidades) afirmaram manter associação com fóruns, coletivos e frentes democráticas.

Sobre o posicionamento do veículo em relação aos assuntos abordados e o tratamento (tipo) dos conteúdos, é possível chegar a uma conclusão: a mídia alternativa assume postura geralmente crítica, não escondendo sua opinião a respeito do assunto em pauta. Diferentemente do que se pode observar em meios de comunicação tradicionais, não há uma preocupação evidente com uma suposta imparcialidade ou isenção. Nota-se também que além dos conteúdos majoritariamente categorizados como opinativos, há uma expressiva parcela de denúncias, principalmente quando as temáticas são segurança pública e racismo. Quando se demonstram

Revista ALTERJOR

Grupo de Estudos Alterjor: Jornalismo Popular e Alternativo (ECA-USP)

Ano 12 - Volume 01 - Edição 25 - Janeiro-Junho de 2022

Av. Professor Lúcio Martins Rodrigues, 443, Cidade Universitária, São Paulo, CEP: 05508-020 


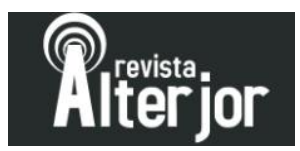

favoráveis, as produções envolvem notícias e a divulgação de ações de cidadania, como o resultado democrático de eleições na América Latina, que podem apontar para a mudança de problemas sociais graves e para o fortalecimento do poder da sociedade civil na garantia e efetivação de direitos.

Declaradamente contrários ao atual governo federal, os veículos analisados corroboram a definição de mídia alternativa estabelecida por Grinberg (1987), opondo-se ao discurso dominante e apresentando conteúdos que transparecem isso. Porém, esses mesmos veículos também evidenciam essa alternatividade em seus processos e suas formas de organização.

Portanto, é seguro afirmar que a ação dessa parte da mídia brasileira busca fortalecer a luta pela democratização da comunicação e nos dá base para formular nossa própria descrição da mídia alternativa. A partir desta pesquisa, podemos entendê-la como aquela que ganha força e se faz extremamente necessária em um momento de resistência e enfrentamento a governos autoritários, que apoia os movimentos sociais e, alinhando-se a eles, age para defender e promover a democracia, bem como os direitos humanos. Não há outra opção.

\section{CONSIDERAÇÕES FINAIS}

Os resultados mostraram ser possível afirmar que a abordagem de temas relacionados aos direitos humanos é expressiva nos veículos analisados e que a mídia alternativa se posiciona declaradamente a favor da luta por direitos e da defesa da democracia, denunciando violações, alinhando-se e dando voz aos movimentos sociais. Além disso, identificamos aspectos técnicos e ideológicos, como o tratamento mais presente nos conteúdos (opinativo), a temática principal (segurança pública), o posicionamento (contrário ao governo atual), os formatos mais utilizados (matérias e reportagens) e as fontes mais consultadas (representantes da sociedade civil).

Os próprios participantes da pesquisa, advogados da causa, sugeriram algumas ações que poderiam potencializar o processo de democratização da comunicação que, como alerta Lima (2011, 2012, 2013), é tão difícil em uma sociedade capitalista e regida por políticas neoliberais. Como apontou a jornalista Laura Capriglione em uma de suas respostas ao questionário de pesquisa, proibir que instituições religiosas e políticos detenham a propriedade de meios de comunicação é um começo.

Também parecem interessantes as propostas de estabelecer critérios de representatividade racial, regional e social e definir uma programação mínima dedicada à educação e à cultura, bem como criar uma emissora pública de qualidade, desvinculada de

\section{Revista ALTERJOR}

Grupo de Estudos Alterjor: Jornalismo Popular e Alternativo (ECA-USP)

Ano 12 - Volume 01 - Edição 25 - Janeiro-Junho de 2022

Av. Professor Lúcio Martins Rodrigues, 443, Cidade Universitária, São Paulo, CEP: 05508-020 


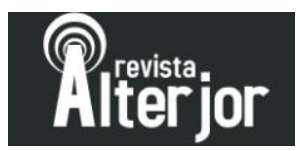

interesses privados. Tudo isso poderia, como apontou Arthur Stabile da Ponte Jornalismo, estar presente em uma lei de meios. Esta, por sua vez, precisaria ser construída em parceria com a sociedade civil e os movimentos sociais que lutam pela democratização da comunicação, para que, juntos, criassem políticas públicas e novas formas de acesso a este bem tão indispensável que é a comunicação.

Em um cenário ameaçador, é revigorante constatar que há no Brasil veículos de comunicação preocupados com a proteção e manutenção da democracia e dos direitos humanos. É uma constatação para fortalecer e encher de esperança a luta social, para que continuemos resistindo e inspirando novos movimentos de resistência.

\section{REFERÊNCIAS}

AGÊNCIA PÚBLICA. Mapa do Jornalismo Independente. 2019. Disponível em: $<$ https://apublica.org/mapa-do-jornalismo/>. Acesso em: 1 dez. 2021.

ATTON, Chris. Alternative media. Londres: SAGE Publications, 2002.

BARDIN, Laurence. Análise de conteúdo. $3^{\mathrm{a}}$ reimp. da $1^{\mathrm{a}}$ ed. São Paulo: Edições 70, 2016.

BAUER, Martin W.; GASKELL, George. Pesquisa qualitativa com texto, imagem e som: um manual prático. $7^{\mathrm{a}}$ ed. Petrópolis: Vozes, 2002.

FLORES, Joaquín Herrera. A reinvenção dos direitos humanos. Florianópolis: Fundação Boiteux, 2009.

GALLARDO, Helio. Teoria crítica: matriz e possibilidade de direitos humanos. $1^{\mathrm{a}}$ ed. São Paulo: Editora Unesp, 2014.

GIL, Antonio Carlos. Como elaborar projetos de pesquisa. 4a ed. São Paulo: Atlas, 2002.

GOÉS, Laércio. Características do Jornalismo Alternativo dos Movimentos Sociais na

Web. Ciber Legenda, 2007. Disponível em:

<https://periodicos.uff.br/ciberlegenda/article/view/36679>. Acesso em: 1 dez. 2021.

GOLDENBERG, Mirian. A arte de pesquisar: como fazer pesquisa qualitativa em ciências

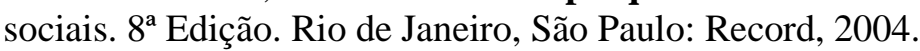

GREENWALD, Glenn. Bem-vindo ao The Intercept Brasil. 2016. Disponível em: <https://theintercept.com/2016/08/02/bem-vindo-ao-the-intercept-brasil/>. Acesso em: $1 \mathrm{fev}$. 2021.

GRINBERG, Máximo Simpson (org.). A comunicação alternativa na América Latina. Petrópolis: Vozes, 1987.

GUARESCHI, Pedrinho. O direito humano à comunicação: pela democratização da mídia. Petrópolis: Vozes, 2013.

JORNALISTAS LIVRES. Quem somos. 2021. Disponível em:

< https://jornalistaslivres.org/quem-somos/>. Acesso em: 30 nov. 2021.

\footnotetext{
Revista ALTERJOR

Grupo de Estudos Alterjor: Jornalismo Popular e Alternativo (ECA-USP)

Ano 12 - Volume 01 - Edição 25 - Janeiro-Junho de 2022

Av. Professor Lúcio Martins Rodrigues, 443, Cidade Universitária, São Paulo, CEP: 05508-020
} 


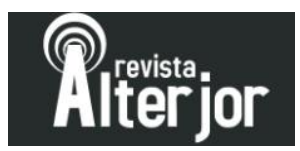

KUCINSKI, Bernardo. Jornalistas e revolucionários: nos tempos da imprensa alternativa. São Paulo: Editora Página Aberta, 1991.

LIMA, Venício Artur de. Liberdade de expressão x liberdade de imprensa: direito à comunicação e democracia. $2^{\text {a }}$ ed. São Paulo: Publisher Brasil, 2012.

LIMA, Venício Artur de. Regulação das comunicações: história, poder e direitos. São Paulo: Paulus, 2011.

LIMA, Venício Artur de; GUIMARÃES, Juarez (orgs). Liberdade de expressão: as várias faces de um desafio. São Paulo: Paulus, 2013.

PERUZZO, Cicilia M. Krohling. Aproximações entre a comunicação popular e comunitária e a imprensa alternativa no Brasil na era do ciberespaço. Revista Galáxia, São Paulo, n. 17, p. 131-146, jun. 2009.

PONTE JORNALISMO. Quem a gente é. 2020. Disponível em:

< https://ponte.org/sobre/>. Acesso em: 30 nov. 2021.

RECUERO, Raquel. Introdução à análise de redes sociais. Salvador: EDUFBA, 2017.

Disponível em: <https://repositorio.ufba.br/ri/handle/ri/24759>. Acesso em: 18 fev. 2021.

SANTOS, Boaventura de Sousa; CHAUÍ, Marilena. Direitos humanos, democracia e desenvolvimento. - $1^{\circ}$ edição. São Paulo: Cortez, 2014. 